\title{
CLONAGEM E CARACTERIZAÇÃO GENÉTICA DE LOCOS HOMÓLOGOS A GENES DE RESISTÊNCIA EM Brassica oleracea L e
}

Zea mays L.

\section{Celia Correia Malvas}

Tese apresentada à Escola Superior de Agricultura "Luiz de Queiroz", Universidade de São Paulo, para obtenção do título de Doutor em Agronomia, Área de Concentração: Fitopatologia.

PIRACICABA

Estado de São Paulo - Brasil

Janeiro - 2003 


\section{CLONAGEM E CARACTERIZAÇÃO GENÉTICA DE LOCOS HOMÓLOGOS A GENES DE RESISTÊNCIA EM Brassica oleracea L. e Zea mays L.}

\section{CELIA CORREIA MALVAS}

Engenheiro Agrônomo

Orientador: Prof Dr LUIS EDUARDO ARANHA CAMARGO

Tese apresentada à Escola Superior de Agricultura "Luiz de Queiroz", Universidade de São Paulo, para obtenção do título de Doutor em Agronomia, Área de Concentração: Fitopatologia.

PIRACICABA

Estado de São Paulo - Brasil

Janeiro - 2003 


\title{
Dados Internacionais de Catalogação na Publicação (CIP)
} DIVISÃO DE BIBLIOTECA E DOCUMENTAÇÃO - ESALQ/USP

\author{
Malvas, Celia Correia \\ Clonagem e carac terização genética de locos homólogos a genes de \\ resistência em Brassica oleracea L e Zea mays L. / Celia Correia Malvas. - - \\ Piracicaba, 2003. \\ 79 p. : il. \\ Tese (doutorado) - - Escola Superior de Agricultura Luiz de Queiroz, 2003. \\ Bibliografia.
}

1. Genes 2. Linhagens vegeta is 3. Marcador genétic o 4. Milho 5.

Oligonucleotídeos 6. Podridão (Doença de planta) 7. Polimorfismo 8. Repolho I. Título

CDD 635.34

"Permitida a cópia total ou parcial deste documento, desde que citada a fonte - O autor" 
Aos meus pais Areovaldo e Audilia, meus irmãos Roberto, Sandra e Marcos, por apoiar todas as minhas decisões e compreender a minha ausência e aos meus sobrinhos Bruno e Michel, pelos incontáveis eu te amo, DEDICO.

"Eu poderia viver recluso numa casca de noz e me considerar rei do espaço infinito"

W. Shakespeare

Ao Renato, pela paciência que torna nossa vida tão serena, com amor, OFEREÇO. 


\section{AGRADECIMENTOS}

Ao Professor Dr. Luis Eduardo Aranha Camargo, pelos ensinamentos, pelo incentivo e pelo exemplo de incansável busca por conhecimentos.

A Dra. Maeli Melotto pela co-orientação, experiência, amizade e longas conversas.

Aos meus pais Areovaldo e Audilia e aos meus irmãos por compreenderem minha ausência e pelo orgulho que sentem por mim.

Aos pequenos Bruno e Michel por não esquecerem dessa tia ausente.

Ao Renato, meu porto seguro, pela paciência, compreenssão nos momentos de ausência, companheirismo e toda felicidade que me dá.

Aos professores do Setor de Fitopatologia pelos ensinamentos durante minha formação acadêmica.

Aos colegas do laboratório de Genética Molecular pela colaboração, amizade e convivência sempre tão agradável.

A Quelmo, Guilherme, Raquel, Alice, Regina, Kátia, Rodrigo, Giovana, Mariana e Cláudia Vitorello, pelos bons momentos.

A Heloísa e Daniela por serem sempre companheiras e a Juliana, Regina e Andréia, que mesmo distantes sempre estiveram presentes.

A Alessandra, Flaviana e Paulo pela acolhida e amizade.

A todos os colegas de pós-graduação do Setor de Fitopatologia.

Aos funcionários Marina, Jéferson, Fernanda, Rodolfo, Sílvia e Pedro pela presteza.

A todos que de alguma forma contribuíram para a realização deste trabalho.

À Fundação de Amparo àPesq uisa do Estado de São Paulo (FAPESP) pela bolsa de estudo e reserva técnica concedida para a realização deste trabalho. 


\section{SUMÁRIO}

LISTA DE FIGURAS .................................................................... viii

LISTA DE TABELAS ............................................................................... x

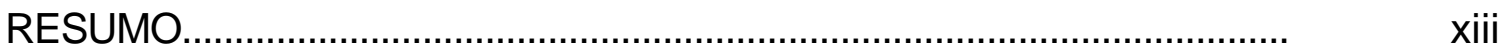

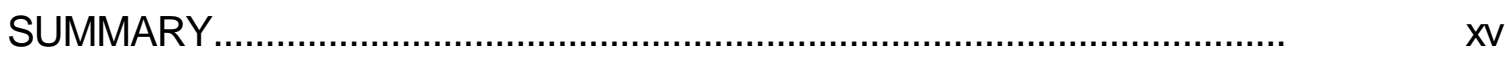

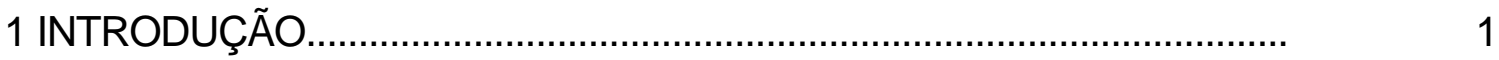

2 REVISÃO DE LITERATURA..............................................................

2.1 Características estruturais de genes de resistência...................................

2.2 Expressão de genes de resistência........................................................

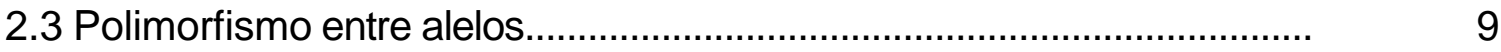

2.4 Clonagem e análise de fragmentos homólogos a genes de

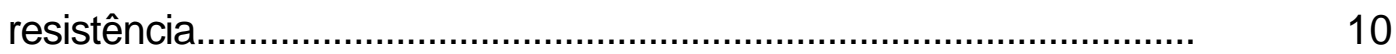

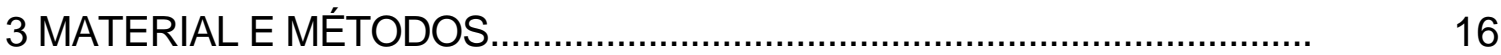

3.1 Clonagem e caracterização genética de um fragmento homólogo ao gene RPS2 em Brassica oleracea...................................................... 16

3.1.1 Material vegetal e extração de DNA..................................................... 16

3.1.2 Clonagem do homólogo ao gene RPS2 ............................................ 17 
3.1.2.1 Amplificação dos fragmentos.

3.1.2.2 Clonagem dos fragmentos BI-16/RPS2 e

3.1.2.3 Construção da biblioteca "shotgun".

3.1.2.4 Transformação de células competentes de Escherichia coli com os fragmentos

3.1.3 Seqüenciamento.

3.1.4 Análise de polimorfismo e desenvolvimento de marcador CAPs

3.1.5 Análise da segregação entre marcador e gene de resistência a Xanthomonas campestris pv. campestris.

3.1.6 Expressão do homólogo B/16/RPS2 em Brassica oleracea.

23

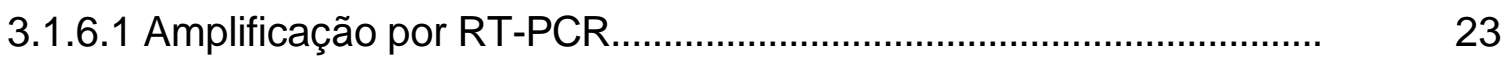

3.1.6.2 Clonagem do fragmento homólogo obtido a partir de DNAc de B 16.25

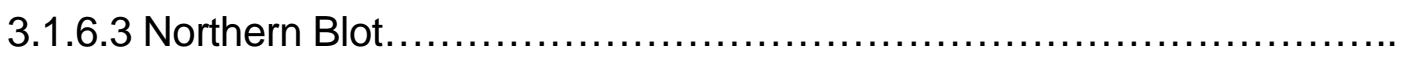

25

3.2 Clonagem e caracterização genética de fragmentos homólogos a genes de resistência em Zea mays.

3.2.1 Material vegetal.

3.2.2 Clonagem de homólogos a genes de resistência em Zea mays.

3.2.2.1 Amplificação dos fragmentos homólogos a genes de resistência.......

3.2.2.2 Amplificação de fragmentos homólogos a ESTs.

3.2.3 Análise de polimorfismo

4 RESULTADOS.

4.1 Clonagem e caracterização genética de um fragmento homólogo ao 
gene RPS2 em Brassica oleracea..

4.1.1 Clonagem do homólogo ao gene RPS2.......................................... 31

4.1.1.1 Amplificação dos fragmentos Bl-16/RPS2 e Lc201/RPS2.................. 31

4.1.1.2 Seqüenciamento dos fragmentos Bl-16/RPS2 e Lc201/RPS2........... 32

4.1.2 Análise de polimorfismo e segregação dos fragmentos BH16/RPS2 e Lc201/RPS2.

4.1.3 Expressão do homólogo B/16/RPS2 em Brassica oleracea.

4.2 Clonagem e caracterização genética de fragmentos homólogos a genes de resistência em Zea mays.

4.2.1 Clonagem de fragmentos em Zea mays............................................. 49

4.2.1.1 Amplificação de fragmentos com os oligonucleotídeos Pics............... 49

4.2.1.2 Digestão dos produtos de PCR nas linhagens parentais.................... 51

4.2.1.3 Seqüenciamento de fragmentos amplificados................................... 51

4.2.2 Análise de cosegregação do fragmento Pic18 ...................................... 52

4.2.3. Clonagem de fragmentos homólogos a ESTs de milho........................ 55

4.2.3.1 Amplificação de fragmentos por meio de oligonucleotídeos baseados em ESTs de milho

4.2.4 Análise de polimorfismo de comprimento por meio de enzima de restrição.

6 CONCLUSÕES. 


\section{LISTA DE FIGURAS}

1 Fragmentos de 2,5 Kb amplificados com os oligonucleotídeos B1F e B1R nas linhagens BH16 e Lc201. 1: marcador de peso molecular 1Kb Ladder (Promega, Madison, WI); 2: linhagem B 16; 3: linhagem 32 Lc201

2 Alinhamento entre as seqüências Br16/RPS2 e Lc201/RPS2. Regiões em caixas são sítios de Xbal. Regiões sublinhadas em preto correspondem ao domínio NBS e em vermelho ao LRR.

3 Alinhamento entre seqüências de aminoácidos dos fragmentos Br 16/RPS2, Lc201/RPS2, RPS2 de B117 (AF180357) e RPS2 de $A$. thaliana (ATU14158). Sublinhado em vermelho indica região NBS do gene RPS2. Sublinhado em preto indica região LRR

4 Esquema representativo do corte da enzima $X b a$ I na seqüência de BI-16/RPS2 e Lc201/RPS2. Barra preta representa os dois fragmentos. Setas e barras vermelhas correspondem aos sítios de restrição e tamanho dos fragmentos gerados em Br16/RPS2, respectivamente. Setas e barras verdes correspondem aos sítios de restrição e tamanho dos fragmentos em Lc201/RPS2, 
respectivamente (Para detalhes, vide texto).

5 Padrão de restrição obtido com digestão dos fragmentos B 16/RPS2, Lc201/RPS2 e do $F_{1} /$ RPS2, com enzima de restrição Xbal. (1) Padrão de peso molecular $1 \mathrm{~Kb}$ Ladder (Promega); (2) $\mathrm{B}$ 16/RPS2; (3) Lc201/RPS2 (4) F F/RPS2 ............................................

6 Padrão de restrição obtido com digestão dos fragmentos B 16/RPS2, Lc201/RPS2 e fragmentos amplificados nos indivíduos $F_{1}$ e $F_{2}$ com enzima de restrição Xbal. (1) Padrão de peso molecular $1 \mathrm{~Kb}$ Ladder (Promega); (2) BL16; (3) Lc201; (4) $F_{1} ;\left(5\right.$ a 20) $F_{2}$

7 Sintomas nas linhagens parentais B116 e Lc201 uma semana após inoculação com isolado PHW 1205 de Xanthomonas campestris pv. campestris.

8 PCR de DNAc obtido de folhas 24 horas após a inoculação com Xanthomonas campestris pv. campestris. (1) $1 \mathrm{~Kb}$ DNA ladder (Promega); (2 e 3) controle positivo com DNA genômico de Br16 e Lc201, respectivamente; (4 e 5) PCR com DNAc de Bl-16 e Lc201, respectivamente; ( 6 e 7) controle negativo com RNA mensageiro........

9 Perfil de hibridização com sonda de $\beta$-actina. Diluições variaram de 10ng à1pg de DNA. Diluição a 1 pg não houve hibridização............... ..

10 Fragmentos das linhagens parentais AG41, AG45 e do híbrido AG41xAG45, amplificados com os oligonucleotídeos específicos Pic18. 1Kb Ladder é o marcador de peso molecular (Promega, 
Madison, WI)

11 Perfil de amplificação do oligonucleotídeo Pic17. Amostra 1: marcador de peso molecular $1 \mathrm{~kb}$ ladder (Promega, Madison, WI); 2: DAS21; 3: DAS6; 4: híbrido DAS21x DAS6, 5: DAS4, 6: DAS6, 7. DAS4x DAS6; 8. DAS95; 9; DAS21; 10: DAS95xDAS21; 11: AG41; 12: AG45; 13:AG41XAG45

12 Fragmentos amplificados com o oligonucleotídeo Pic18 em indivíduos da população segregante para resistência a Exserohilum turcicum. $1 \mathrm{~Kb}$ Ladder encontra-se na primeira linha de cada gel. Os demais são indivíduos da população segregante.

13 Fragmentos obtidos com os oligonucleotídeos LRR (A) e PDR (B). 1: marcador de peso molecular $1 \mathrm{~Kb}$ Ladder (Promega, Madison, WI); 2: DAS21; 3: DAS6; 4: híbrido DAS21x DAS6, 5: DAS4, 6: DAS6, 7. DAS4x DAS6; 8. DAS95; 9; DAS21; 10: DAS95xDAS21; 11: AG41; 12: AG45; 13:AG41XAG45.

14 Perfil de bandeamento obtido pela digestão dos fragmentos amplificados pelo iniciador PDR nos parentais AG41 e AG45 e no híbrido AG41xAG45 com Alul. 1: $1 \mathrm{~Kb}$ DNA Ladder (Promega, Madison, WI) 2, 3 e 4 linhagem AG41, AG45 e híbrido AG41xAG45, sem digerir, respectivamente; 5, 6 e 7, AG41, AG45 e AG41xAG45 digeridos com Alul, respectivamente.

15 Perfil de bandeamento obtido pela digestão dos fragmentos 
amplificados pelo iniciador LRR com a enzima Alul nas linhagens parentais. 1Kb Ladder (Promega, Madison, WI); 2: linhagem DAS21; 3: linhagem DAS6; 4: híbrido DAS21x DAS6, 5: DAS4, 6: DAS6, 7. DAS4x DAS6; 8. DAS95; 9; DAS21; 10: DAS95xDAS21; 11: AG41;

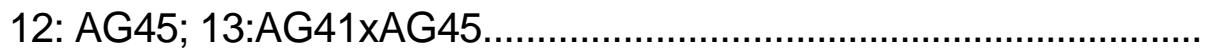




\section{LISTA DE TABELAS}

Página

1 Porcentagem de homologia, dados pela razão entre nucleotídeos idênticos e número total de nucleotídeos e nível de significância (valor-E) para as comparações entre as seqüências Bl-16/RPS2 e Lc201/RPS2 e seqüências depositadas no banco de dados do NCBI..

2 Área foliar lesionada (AFL) e genótipo obtido pela restrição com a enzima $X$ bal na população $F_{2}$

3 Fenótipos segundo a escala de notas descrita por Esteves (1989) e genótipos no loco Pic18 de indivíduos suscetíveis derivados de AG41 x AG45.

4 Seqüências dos oligonucleotídeos sintetizados a partir de seqüências homólogas a ESTs de resistência em milho. 


\title{
CLONAGEM E CARACTERIZAÇÃO GENÉTICA DE LOCOS HOMÓLOGOS A GENES DE RESISTÊNCIA EM Brassica oleracea L. e Zea mays L.
}

\author{
Autor: CELIA CORREIA MALVAS \\ Orientador: Prof. Dr. LUIS EDUARDO ARANHA CAMARGO
}

\section{RESUMO}

O presente trabalho teve por objetivo identificar fragmentos homólogos a genes de resistência em Brassica oleracea e Zea mays, por meio da amplificação por PCR, utilizando oligonucleotídeos homólogos a regiões conservadas de genes de resistência de plantas. Em $B$. oleracea, os oligonucleotídeos foram desenhados com base na seqüência de um gene homólogo ao RPS2 de Arabidopsis thaliana descrito em B. oleracea. Um fragmento de $2,5 \mathrm{~Kb}$ foi amplificado em duas linhagens. Os fragmentos amplificados apresentaram polimorfismo de comprimento entre as linhagens, gerando um marcador molecular. Este marcador foi utilizado em uma população $\mathrm{F}_{2}$ segregante para resistência a Xanthomonas campestris pv. campestris oriunda do cruzamento entre as linhagens B116 e Lc201. O marcador, no entanto, não apresentou-se ligado a nenhum gene de resistência a este patógeno. Análise da expressão por meio de RT-PCR detectou a expressão do fragmento homólogo nas linhagens resistente e suscetível de $B$. oleracea com e sem inoculação, indicando que o gene é expresso constitutivamente. Em $Z$. mays, oligonucleotídeos sintetizados com base em seqüências de milho 
homólogas a genes de resistência, denominadas Pics, e a ESTs de milho, também homólogos a genes de resistência, foram utilizados para amplificação em linhagens resistente e suscetível a Exserohilum turcicum, Colletotrichum graminicola e Phaeosphaeria maydis. Um par de oligonucleotídeos amplificou um fragmento polimórfico entre as linhagens resistente e suscetível a $E$. turcicum. Este foi utilizado em uma população segregante, mas também não observou-se ligação com o gene $\mathrm{Ht}$ de resistência a $E$. turcicum. Nas demais linhagens, os fragmentos foram monomórficos. Os oligonucleotídeos baseados em ESTs amplificaram fragmentos em todas as linhagens parentais. Esses fragmentos foram digeridos com enzimas de restrição, mas não apresentaram polimorfismo entre nenhuma das linhagens. Os resultados indicaram que a estratégia de utilização de seqüências conservadas é eficiente para amplificação de genes homólogos. O polimorfismo entre estes homólogos pode ser usado como marcador molecular para detecção de genes de interesse. Todavia, nem sempre estes marcadores estão ligados a esses genes. 


\title{
CLONING AND GENETIC CHARACTERIZATION OF RESISTANCE GENE HOMOLOGS OF Brassica oleracea L. AND Zea mays L.
}

\author{
Author: CELIA CORREIA MALVAS \\ Adviser: Prof. Dr. LUIS EDUARDO ARANHA CAMARGO
}

\section{SUMMARY}

The aim of this work was to identify homologs of resistance genes in Brassica oleracea and Zea mays by PCR amplification using primers based on conserved domains of plant resistance genes. In B. oleracea, the primers were based on the sequence of a homolog of the Arabidopsis thaliana RPS2 gene previously described in B. oleracea. A $2.5 \mathrm{~Kb}$ fragment was amplified on two lines. These fragments showed length polymorphisms between lines, based on which a molecular marker was developed. This marker was used in a $F_{2}$ population, derived from the crossing between the inbred lines Bł16 and Lc201, and which segregates to resistance to Xanthomonas campestris pv. campestris. The marker, however, was not linked to any Xcc resistance gene. Expression analyses by RT-PCR detected the expression of these homologs on both resistant and susceptible lines with and without inoculation, indicating that the gene is constitutively expressed. In Z. mays, primers based on resistance gene homologs sequences, named Pics, and on maize ESTs homologous to disease 
resistance genes, were used to amplify genomic fragments on resistant and susceptible lines to Exserohilum turcicum, Colletotrichum graminicola and Phaeosphaeria maydis. A set of primers amplified a polymorphic fragment between lines resistant and susceptible to E. turcicum. This fragment was used in a segregating population, but no linkage was detected between this marker and the E. turcicum resistance gene $\mathrm{Ht}$. Among the other lines, the fragments were not polymorphic. The primers based on ESTs amplified fragments on all parental lines. These fragments were digested with restriction enzymes but did not reveal any polymorphism between lines. The results indicated that the strategy of using conserved sequences is efficient to amplify disease resistance gene homologs. The polymorphism among these homologs may be used as a molecular marker, but these markers are not always linked to disease resistance genes. 


\section{INTRODUÇÃO}

Genes de resistência de plantas a patógenos apresentam homologia entre si, particularmente em certos domínios conhecidos, tais como as repetições do aminoácido leucina, ou LRR (do termo inglês Leucine Rich Repeats), e os sítios de adesão de nucleotídeos, ou NBS (Nucleotide Binding Sites). Estes domínios podem estar envolvidos no fenômeno de reconhecimento do patógeno pelo hospedeiro durante o processo de infecção.

A descoberta da existência de similaridades estruturais entre genes de resistência possibilitou a interessante estratégia de identificar genes homólogos a genes de resistência em diversas outras espécies vegetais por meio da técnica de PCR. A seqüência nucleotídica destes domínios pode ser usada para gerar oligonucleotídeos e amplificar fragmentos genômicos homólogos a genes de resistência em espécies distantes e correlatas. Em vários casos, estes fragmentos estão ligados a genes de resistência previamente conhecidos.

O gene RPS2 de Arabidopsis thaliana confere resistência a Pseudomonas syringae pv. tomato (Bent et al., 1994; Mindrinos et al., 1994). Este gene, localizado no cromossomo 4, codifica uma proteína de 909 aminoácidos e contém os motivos NBS e LRRs. Alto polimorfismo em nível de 
seqüência foi demonstrado na região terminal 3' (Caicedo et al., 1999). Wroblewsky et al. (2000) descreveram a existência de uma cópia deste gene em Brassica oleracea. Este homólogo apresentou $85 \%$ de identidade com seqüências de nucleotídeos de $A$. thaliana e $86 \%$ de identidade entre aminoácidos. O gene não possui nenhum íntron e está presente em apenas uma cópia em $B$. oleracea, a exemplo de seu homólogo de $A$. thaliana.

No presente estudo, os objetivos foram amplificar fragmentos homólogos a genes de resistência em linhagens de $B$. oleracea e Zea mays, identificar polimorfismos entre estas linhagens e utilizá-los como marcadores moleculares em populações $\mathrm{F}_{2}$ segregantes para resistência.

Primeiramente, oligonucleotídeos baseados na seqüência de fragmentos homólogos a genes de resistência previamente mapeados foram utilizados para amplificar fragmentos em linhagens das espécies vegetais acima mencionadas. Em B. oleracea, oligonucleotídeos foram desenhados baseandose na seqüência de um gene homólogo ao RPS2 de $A$. thaliana previamente descrito em $B$. oleracea. Os fragmentos amplificados nas linhagens parentais foram seqüenciados, digeridos e usados como marcador molecular em uma população $F_{2}$ de $B$. oleracea segregante para resistência a Xanthomonas campestris pv. campestris. Concomitante a isso foi estudada a expressão do fragmento homólogo nas linhagens resistente e suscetível. Em Z. mays, oligonucleotídeos baseados em seqüências previamente descritas e a ESTs 
homólogos a genes de resistência foram utilizados para amplificação em linhagens resistente e suscetível a vários patógenos de milho. 


\section{REVISÃO DE LITERATURA}

\subsection{Características estruturais de genes de resistência}

Genes de resistência raça-específicos, que operam no sistema gene-agene proposto por Flor (1971), podem ser divididos em dois grandes grupos: aqueles que apresentam uma região rica em leucina (LRRs - leucine rich repeats) e aqueles que não possuem este domínio. No primeiro grupo, encontramos a maioria dos exemplos, ao passo que no segundo encontramos o gene Pto de tomateiro, que confere resistência a Pseudomonas syringae pv. tomato. Este gene codifica uma proteína quinase responsável pela fosforilação de outras enzimas envolvidas na reação de defesa da planta (Martin et al., 1993). Entre os genes que apresentam LRRs, temos exemplos que só apresentam estas regiões, mas a grande maioria apresenta também sítios de adesão de nucleotídeos (NBS - nucleotide binding sites). Há ainda aqueles que apresentam, além de LRRs, função de proteína quinase, mas nenhum NBS (Hulbert et al., 2001).

Estes domínios podem estar envolvidos no fenômeno de reconhecimento do patógeno pelo hospedeiro durante o processo de infecção (Hutcheson, 1998; 
Schaal \& Olsen, 2000; Dangl \& Jones, 2001; Bergelson et al., 2001). Proteínas contendo os motivos NBS e LRRs supostamente reconhecem produtos extracelulares de genes de avirulência de patógenos e iniciam as respostas de defesa ao enviar sinais para outras células do hospedeiro. Proteínas que contêm LRRs são proteínas que apresentam séries do amino-ácido leucina repetidos em número de 24 ou mais a intervalos regulares, podendo conter ainda outros resíduos hidrofóbicos, asparaginas e prolinas. Os motivos de leucina geram uma estrutura terciária semelhante a uma mola, com cada hélice representando um motivo de leucina repetido. A função dos LRRs parece ser de mediação da interação entre proteínas, podendo atuar extracelularmente como receptor do elicitor codificado pelo gene de avirulência do patógeno ou intracelularmente, num passo anterior à via de transdução dos sinais envolvidos no processo de resistência (Bent et al., 1994; Bent, 1996). Supõe-se que a porção amino terminal do domínio de LRR, que é altamente variável, possui papel mais importante no reconhecimento que a porção carboxi terminal, que é mais conservada (Dixon et al., 1996).

Interações entre genes de resistência e de avirulência, que sugerem a função de reconhecimento dos primeiros, foram demonstradas quando mutações dentro da porção C-terminal do gene avrRpt2 de Pseudomonas syringae impediu o reconhecimento do patógeno por $A$. thaliana. Aparentemente a região C-terminal do gene AvRpt2 é responsável pelo início da reação de hipersensibilidade causada pelo gene RPS2. Postula-se que a região LRR do gene RPS2 liga-se diretamente à proteína do gene de 
avirulência AvRpt2. Alelos do gene avrRpt2 com mutação na porção C-terminal foram incapazes de causar reação de hipersensibilidade típica da interação do reconhecimento pelo RPS2. Ao mesmo tempo, seis alelos do RPS2 com mutação em apenas um aminoácido do domínio LRR foram ineficientes para reconhecer 0 avrRpt2, demonstrando a importância destes domínios para o reconhecimento (Axtel et al., 2001; Banerjee et al., 2001). Os genes Cf-9 e Cf-2, que conferem resistência de tomateiro a isolados de Cladosporium fulvum portadores dos genes de avirulência Avr9 e Avr2, respectivamente, são aqueles que apresentam somente regiões com motivos repetidos de leucina (Jones et al., 1994; Dixon et al., 1996). Todavia, não foram demonstradas evidências de ligação entre o gene Cf9 de tomateiro e o correspondente avr9 de Cladosporium fulvum, sugerindo a presença de um terceiro integrante mediando o processo de reconhecimento do gene de avirulência pelo gene de resistência. Um sítio de alta afinidade para ligação, ou HABS (High afinity binding site), presente na membrana plasmática de plantas de tomate, fumo, batata e petunia parece ser este terceiro agente, uma vez que está altamente correlacionado com necrose induzida pelo gene avr9 (Lurderer et al., 2001). O envolvimento de um terceiro componente foi descrito para os genes AvrPto de P. s. pv. tomato e AvrRpt2 de P. syringae por Arabidopsis. Estes resultados permitem supor que o fenômeno de reconhecimento elicitor-receptor seja mais complexo que o suposto até o momento.

A maioria dos genes apresenta, além dos LRRs, sítios de adesão de nucleotídeos.Neste grupo encontram-se os genes de Arabidopsis RPS2, RPM1 
e RPP5, repectivamente de resistência a $P$. s. pv. tomato, $P$. syringae e Peronospora parasitica (Bent et al., 1994; Mindrinos et al., 1994; Grant et al., 1995; Parker et al., 1997); o gene $N$ que confere resistência ao vírus do mosaico do fumo em tabaco (Whitham et al., 1994); os genes $L 6$ e $M$, ambos de resistência de linho a ferrugem (Lawrence et al., 1995; Anderson et al., 1997); o gene IC2 de resistência de tomateiro a Fusarium oxysporum f. sp. Iycopersici; e o gene Xa-1 de resistência de arroz à raça 1 de Xanthomonas oryzae pv. oryzae (Ori et al., 1997; Yoshimura et al., 1998). Sítios de adesão de nucleotídeos, também referidos como "P-loops", ocorrem em diversas proteínas e são responsáveis por atividades de ligação ao ATP ou GTP, tais como subunidades da ATP sintetase e fatores de elongação do ribossomo. A presença destes domínios em diversas proteínas de genes de resistência sugere que estes sítios podem estar envolvidos na ativação de proteínas quinases e proteínas transportadoras (Hammond-Kosak \& Jones, 1997).

Finalmente, temos ainda uma outra classe de genes de resistência caracterizada por apresentar LRRs e também função de proteína quinase, mas nenhum NBS. Como exemplo desta classe, temos o gene Xa-21 que confere resistência à raça 6 de $X$. o. pv. oryzae (Song et al., 1995) em arroz e o gene Lr10 de resistência de trigo a Puccinia recondita (Feuillet et al., 1997). O gene Xa-21 é um membro de uma família de sete genes e possui uma estrutura diferenciada dos outros genes, apresentando três domínios: um LRR extracelular, um domínio transmembrana e um quinase intracelular. A sua 
expressão é constitutiva, mas aumenta progressivamente do estado juvenil para plantas adultas (Song \& Goodman, 2001; Wang et al., 1996).

Genes de resistência freqüentemente são encontrados em múltiplas cópias agrupadas no genoma. Teoricamente, clusters de genes funcionariam como um reservatório de mutação. No genoma de Arabidospsis, 182 genes formam 20 clusters de genes, sendo que quinze destes contêm genes que possuem o motivo LRR (Bergelson et al., 2001). Em tomate, os genes Pto, Fen, Prf e Cfs também aparecem em clusters. (Hulbert et al., 2001; Aarts et al., 1998). A organização em clusters de genes contendo os domínios NBS-LRRs mostrou-se conservada entre membros de diferentes tribos (Zhu et al., 2002; Lee et al., 2001). Para as monocotiledôneas, embora não exista uma exata colinearidade quanto à localização dos genes homólogos no mapa de arroz, cevada e milho, existe uma organização geral comum entre estas espécies. Dentro destes clusters existe uma maior ocorrência de duplicação e recombinação entre os genes. Recombinações entre alelos do gene $L$ de linho, geraram novos alelos com especificidades diferentes para outras raças. Esse arranjo estrutural dos genes homólogos permite um melhor entendimento dos mecanismos evolucionários destes dentro das diferentes espécies (Leister et al., 1998; Hulbert et al., 2001). 


\subsection{Expressão de genes de resistência}

Pouco se sabe sobre a expressão dos genes de resistência. A maioria dos genes estudados até o momento apresenta expressão constitutiva. O nível de expressão destes genes, no entanto, quase sempre é baixo. Os genes RPP5 de Arabidopsis e L6 de linho são bons exemplos disso. O gene RGC2 homólogo ao $D m 3$ de alface também apresenta expressão constitutiva, em baixo nível. (Shen et al., 2002). O gene Xa-1 de resistência àraça 1 de X. o. pv. oryzae de arroz, por sua vez, apresenta expressão induzida. O RNA mensageiro foi detectado por RT-PCR, dos três até os 15 dias após inoculação com o patógeno e também em plantas inoculadas com água, indicando que o gene também é expresso em resposta àinjúria. O acúmulo de RNA mensageiro acompanhou o crescimento da bactéria dentro dos tecidos foliares, indicando que o acúmulo dá-se pela indução do patógeno. O gene Pib de resistência de arroz a Magnaporthe grisea também apresenta expressão induzida tanto por estirpes de M. grisea como por condições ambientais (Yoshimura et al., 1998; Song \& Goodman, 2001).

\subsection{Polimorfismo entre alelos}

Polimorfismos em alelos de genes de resistência podem ser determinantes para a característica de resistência ou suscetibilidade. Alelos de suscetibilidade, de maneira geral, ocorrem por mutação em alelos de 
resistência (Bergelson et al., 2001). Até o momento, entretanto, pouco é conhecido sobre a dinâmica da evolução molecular de genes de resistência. No loco RPS2, alelos de resistência são geneticamente mais similares entre si do que alelos de suscetibilidade. Num estudo de evolução molecular, o gene RPS2 apresentou um nível de polimorfismo de 1,26\%, sendo que aproximadamente metade deste polimorfismo resultou em alteração de aminoácidos e 70\% destes casos foram alterações não conservadas. Este nível de polimorfismo geralmente não é encontrado em plantas e demonstra que, provavelmente, o RPS2 é um gene que evolui rapidamente (Caicedo et al., 1999). Para o loco RPM1, entretanto, linhagens de $A$. thaliana suscetíveis a $P$. s. pv. maculicola não apresentam o gene. Análise das regiões adjacentes ao gene em A. thaliana e $A$. lyrata revelou divergência de seqüência de $10 \%$, um valor alto que indica que provavelmente o polimorfismo foi gerado no momento da especiação entre as duas espécies (Bergelson et al., 2001). Estes dados são corroborados pelo trabalho de Grant et al. (1998), que sugerem a ocorrência de eventos de deleção independentes do gene RPM1 em Brassica napus e A. thaliana.

\subsection{Clonagem e análise de fragmentos homólogos a genes de resistência}

Uma maneira alternativa para a clonagem de genes de resistência, que não a clonagem baseada em mapeamento ou clonagem pelo uso de elementos de transposição, pode ser a utilização de seqüências conservadas entre genes já clonados. 
A existência de similaridades estruturais entre genes de resistência possibilitou a interessante estratégia de identificar genes homólogos a genes de resistência em outras espécies vegetais por meio da PCR e oligonucleotídeos homólogos æ̀s regiões conservadas dos genes de resistência, em particular æ̀s regiões ricas em leucina. Em muitos casos, estes fragmentos possuem alta homologia com genes de resistência clonados e mostram-se ligados a outros ainda não clonados, mas já identificados fenotipicamente.

A vantagem da utilização de homólogos como marcadores moleculares em trabalhos de mapeamento é que estes podem representar genes em potencial. Embora nem todos homólogos amplificados sejam funcionais ou estejam ligados a genes conhecidos, há a possibilidade de que estes estejam envolvidos em alguma via de transdução de sinais dentro da planta (Chen et al., 1998). Genes homólogos ao gene Cf-9 de tomateiro, por exemplo, foram mapeados junto a este no braço curto do cromossomo 1 de tomateiro e podem estar envolvidos no mecanismo de reconhecimento de outros genes de avirulência presentes em raças de Cladosporium fulvum portadoras dos genes Avr4 e Avr9 (Parniske et al., 1999).

Fragmentos amplificados por PCR a partir de oligonucleotídeos de seqüências homólogas a regiões conservadas de genes de resistência são denominados de resistance like-genes (RLGs) ou resistance gene analogs (RGAs). Os primeiros trabalhos que relataram 0 uso de seqüências conservadas entre genes para identificar seqüências similares em outras espécies foram realizados por Kanazin et al. (1996) e Yu et al. (1996). Os 
primeiros autores utilizaram oligonucleotídeos baseados nas seqüências conservadas da região NBS dos genes $N$, RPS2 e $L 6$ para amplificar DNA de soja. Foram amplificadas nove classes de seqüências distintas entre si que apresentaram homologia de até $66 \%$ com os genes de resistência. Alguns destes mostraram-se ligados a genes de resistência a importantes doenças da cultura. Paralelamente, Yu et al. (1996) utilizaram oligonucleotídeos baseados na homologia entre a região de adesão de nucleotídeos (NBS) dos genes $\mathrm{Ne}$ RPS2 para amplificar fragmentos também de soja. Os fragmentos foram seqüenciados e arranjados em três classes de similaridade. Quando utilizados como marcadores genéticos, mostraram-se ligados a outros genes de resistência previamente identificados. A partir destes, vários outros trabalhos relataram o uso da técnica com sucesso nas mais diferentes espécies vegetais tais como arroz, cevada, milho e trigo (Collins et al., 1998; Collins et al., 2001; Seah et al., 1998; Leister et al., 1999; Mago et al., 1999), batata, alface, maçã, girassol, banana, Arabidopsis e Brassica (Leister et al., 1996; Shen et al., 1998; Vinatzer et al., 2001; Gedil et al., 2001; Wiame et al., 2000; Botella et al., 1997; Aarts et al., 1998; Vicente \& King, 2001). As regiões NBS e LRR são as mais utilizadas para desenho de oligonucleotídeos. Em trigo, entretanto, o gene Lrk10 foi isolado usando oligonucleotídeos baseados em domínios de quinase (Feuillet et al., 1997).

O nível de similaridade entre as seqüências amplificadas é bastante variável podendo ser de até $58 \%$, em alface, chegando até a $89 \%$ em espécies como batata. De maneira geral, seqüências com mais de $50 \%$ de similaridade 
entre si ocorrem de maneira agrupada (cluster) no genoma. Além disso, a homologia a seqüências de outros genes de resistência é variável, independente da espécie analisada (Leister et al., 1996; Shen et al., 1998). Em linhagens quase isogênicas de tomateiro foram obtidas múltiplas cópias de homólogos aos genes que contêm LRRs e NBS e aqueles que não contêm NBS. Seqüências homólogas amplificadas em linhagens de tomateiro contendo os genes $T m$-1 e Tm-2 de resistência ao vírus do mosaico do tomateiro (ToMV) apresentaram homologia com os genes RPS2 e $N$, que possuem NBS e LRR, e com os genes Cf2 e Cf9, que possuem somente LRR (Ohmori et al., 1998)

A maioria dos fragmentos homólogos está geneticamente ligada a outros genes de resistência previamente conhecidos. Duas famílias de fragmentos homólogos co-segregaram com genes de resistência a míldio em alface, por exemplo. Em vários casos, estes fragmentos estão ligados aos mais diversos patógenos, como acontece com os genes Gro1 e $R 7$ de resistência a Globodera rostocchiensis e a Phytophythora infestans, respectivamente, em batata. Em outros casos, esses fragmentos são os próprios genes. Um dos genes pertencente àclasse de genes candidatos denominada de RGC2B de alface, foi recentemente implicado na expressão do gene $D m 3$ (Shen et al., 2002). Uma mutação de ponto provocou alteração no códon de terminação na seqüência de seis mutantes do gene $R G C 2$. Todos os mutantes foram suscetíveis a isolados de Bremia lactucae de diferentes regiões. Plantas suscetíveis transformadas com o gene RGC2 não foram resistentes a isolados de $B$. lactucae que não 
eram portadores do gene $A v r 3$, comprovando a especificidade da relação entre o gene de resistência e o gene de avirulência.

A despeito da grande utilização de homólogos para identificação de monogenes de resistência, estes também podem ser usados para o mapeamento de genes pertencentes a sistemas poligênicos de resistência quantitativa. Em batata, uma região genômica com 50 a $60 \%$ de efeito na expressão do fenótipo de resistência ao vírus do enrolamento da folha PLRV (Potato leafroll virus) foi detectada por um homólogo ao gene $N$ de fumo. $A$ seqüência do homólogo $P L R V .1$ foi utilizada para desenvolver um marcador do tipo SCAR com vistas a sua utilização em um programa de selecão (Marczewski et al., 2001).

Baseando-se na homologia de seqüências conservadas entre os genes L6, N, RPP5, RPM1, RPS2 e I2C-1, Collins et al. (1998) identificaram onze classes de seqüências em milho, as quais foram utilizadas como marcadores e localizadas em um mapa genético. Os resultados mostraram que várias destas seqüências localizaram-se em regiões contendo locos de resistência já conhecidos, como por exemplo o gene $H$ t de resistência a Exserohilum turcicum, e alguns locos de resistência à ferrugens em vários cromossomos. Para verificar a ligação destas seqüências com genes de resistência a ferrugens, famílias segregantes para os genes rp1, rp3 e rp4 foram estudadas. Para os locos rp1 e rp3, não foi observado nenhum recombinante entre os locos e os RLGs, indicando que as seqüências estão muito próximas a estes genes ou são os próprios genes. Entretanto, para o loco rp4 foram observados 
indivíduos recombinantes, indicando que o RLG está apenas ligado a este gene. Vários outros genes de resistência, entretanto, não foram identificados, como no caso dos genes $h t 2, h t n 1, h m 2$ e msv1, mostrando que o uso de seqüências homólogas pode ser eficiente para a detecção de genes de resistência mas pode falhar em alguns casos.

Em Brassica oleracea, Wroblewsky et al. (2000) descreveram um homólogo do RPS2. Este homólogo apresentou 85\% de identidade com seqüências de nucleotídeos de $A$. thaliana e $86 \%$ de identidade entre aminoácidos. Uma cópia do gene foi detectada também em $B$. oleracea e nenhum íntron como em $A$. thaliana. As mutações encontradas foram usadas para estudar a evolução de espécies do gênero Brassica e permitiram a separação entre as diferentes tribos, confirmando a separação taxonômica. O maior número de substituições nucleotídicas foi observado entre tribos. 


\section{MATERIAL E MÉTODOS}

Fragmentos homólogos a genes de resistência foram amplificados em linhagens de Brassica oleracea e Zea mays e em populações desenvolvidas a partir dos cruzamentos destas. As populações segregantes foram utilizadas para análise dos marcadores moleculares desenvolvidos a partir dos fragmentos amplificados. A metodologia será descrita separadamente para cada espécie.

\subsection{Clonagem e caracterização genética de um fragmento homólogo ao gene RPS2 em Brassica oleracea}

\subsubsection{Material vegetal e extração de DNA}

A população de Brassica oleracea é uma população $F_{2}$ obtida do cruzamento entre a linhagem Badger Inbred-16 e Lc201. A linhagem Badger Inbred-16 é resistente a Xanthomonas campestris pv. campestris e LC201 é uma linhagem de ciclo curto e suscetível (Camargo et al., 1995; Malvas et al., 1999). 
Para extração de DNA das linhagens parentais e dos indivíduos segregantes utilizou-se o protocolo de Hoisington et al. (1994).

\subsubsection{Clonagem do homólogo ao gene RPS2}

\subsubsection{Amplificação dos fragmentos}

Dois oligonucleotídeos foram sintetizados com base nas extremidades da seqüência do gene homólogo ao gene RPS2 do ecotipo B117 de B. oleracea gb:AF180357.1 (Wroblewski et al., 2000). O desenho dos oligonucleotídeos foi feito com programa Primer 3 (http://alces.med.umn.edu/bin/webprimers). Os oligonucleotídeos B1F 5'-GCAGGACATTAAGACTGATCTTAAGC-3' e B1R 5'GCTGGCAAGTTTGGCTGGACCCTTTCC- ${ }^{3}$, foram utilizados para amplificação com 0 seguinte protocolo: $1 \mu \mathrm{l}$ de DNA (150ng/ $\mu \mathrm{l}), 0,25 \mu \mathrm{M}$ de cada oligonucleotídeo, 0,5 mM de dNTPs (Life Technologies, Rockeville, MD), 1x de tampão da enzima e 3 U de Taq DNA polimerase Pfu (Promega, Madison, WI.). O volume final foi de $50 \mu$ l. A amplificação foi realizada em termociclador PTC 100 (MJ Research Inc., Watertown, MA). O programa de amplificação foi composto por uma desnaturação inicial a $94^{\circ} \mathrm{C}$ por cinco minutos; seguida por 30 ciclos de desnaturação a $94^{\circ} \mathrm{C}$ por um minuto, hibridização a $65^{\circ} \mathrm{C}$ por dois minutos e extensão a $72^{\circ} \mathrm{C}$ por cinco minutos. Seguiu-se uma extensão final por 15 minutos a $72^{\circ} \mathrm{C}$. As amostras foram submetidas à eletroforese em gel de agarose $1 \%$. Após separação dos fragmentos, o gel foi corado em uma solução 
de $0,5 \mu \mathrm{g} / \mathrm{ml}$ de brometo de etídio. O produto de amplificação foi visualizado por exposição à luz ultravioleta e registrado por aparelho Image Master VDS (Pharmacia Biotech, San Francisco, CA). Os fragmentos amplificados foram denominados Bl16/RPS2 e Lc201/RPS2.

\subsubsection{Clonagem dos fragmentos Bl-16/RPS2 e LC201/RPS2}

Para seqüenciamento das extremidades 5' e 3', os fragmentos B 16/RPS2 e Lc201/RPS2 foram clonados em vetor pGEM. Para ligação no vetor, o fragmento foi adicionado de uma adenina nas extremidades 5'. Para tal, adotou-se o seguinte protocolo: $5 \mu \mathrm{L}$ do produto de PCR, 1x de tampão da enzima, 1,25 $\mathrm{mM}$ de $\mathrm{MgCl}_{2}, 0,2 \mathrm{mM}$ de dATP, $5 \mathrm{U}$ de Taq DNA Polimerase (Promega, Madison, WI) e água estéril para $20 \mu \mathrm{L}$. A reação foi incubada por 30 minutos a $70^{\circ} \mathrm{C}$ e $5 \mu \mathrm{L}$ foram utilizados para a reação de ligação. A ligação consistiu de $5 \mu$ do produto de PCR, 50 ng de vetor pGEM T easy, tampão de ligação 1x e 3 U de T4 DNA ligase em um volume de reação de $10 \mu$ l.

\subsubsection{Construção da biblioteca "shotgun"}

Para realizar o seqüenciamento do fragmento de 2,5 Kb foi necessária a construção de uma sub-biblioteca de fragmentos de aproximadamente 800 pares de bases por meio da sonicação dos fragmentos, numa abordagem semelhante ao seqüenciamento aleatório denominada ‘shotgun” (Green, 1997). 
Os produtos de PCR (item 3.1.2.1) foram sonicados em aparelho Ultrasonic Homogenizer (Cole Parmer) por 30 segundos a $75 \%$ de intensidade sem interrupção. Para o reparo das extremidades dos fragmentos, foi utilizado o seguinte protocolo: $20 \mu \mathrm{l}$ do DNA sonicado, $25 \mu \mathrm{M}$ de dNTPs, $5 \mu$ de tampão da enzima 1x, 2,5 U da enzima T4 DNA Polimerase (Promega Corp., Madison, Wi) e água para completar volume final de $50 \mu$ l. A reação foi incubada por 45 minutos em estufa a $37^{\circ} \mathrm{C}$. A seguir, foi adicionado $1 \mu \mathrm{l}$ de enzima Klenow e a reação foi mantida em temperatura ambiente por 15 minutos.

Para obtenção de fragmentos de 500 a 800 pares de base, estes foram eluídos de gel de agarose com o kit Sephaglas Band prep (Amersham Pharmacia Biotech, Piscataway, NJ). Toda a amostra foi utilizada para eletroforese em gel de agarose 1\% com tampão TBE 1x. Pedaços de $250 \mathrm{mg}$ de gel de agarose foram cortados na região dos pesos moleculares desejados e adicionados a tubos contendo $250 \mu \mathrm{l}$ de solução solubilizadora de gel do kit e 5 $\mu \mathrm{l}$ de ácido acético glacial. Estas amostras foram incubadas em banho-maria por 10 minutos a $60^{\circ} \mathrm{C}$ e a seguir adicionadas de $5 \mu \mathrm{l}$ de suspensão de sílica (Sephaglas BP), sob leve agitação por cinco minutos. Ao final, as amostras foram centrifugadas por 30 segundos. $O$ sobrenadante foi transferido para novos tubos e novamente centrifugado. Adicionou-se $80 \mu \mathrm{l}$ da solução de lavagem do kit contendo etanol por duas vezes consecutivas, seguidas de centrifugação. $O$ precipitado foi seco a temperatura ambiente por 30 segundos e ressuspendido em $20 \mu$ de água ultrapura estéril durante cinco minutos. 
Amostras foram centrifugadas por um minuto e o sobrenadante utilizado para clonagem no vetor puc18.

Para ligação, utilizou-se $6 \mu \mathrm{l}$ de DNA sonicado conforme descrito acima, $50 \mathrm{ng}$ de vetor pUC18 Smal/Bap, $2 \mu \mathrm{l}$ de tampão de ligação, 10 mM de DTT, 5,5 U da enzima T4 DNA ligase (Amersham Pharmacia Biotech, Piscataway, NJ) e água estéril para completar um volume final de $20 \mu$. A reação foi incubada a $15^{\circ} \mathrm{C}$ por um período de 12 horas. As amostras foram armazenadas a $-20^{\circ} \mathrm{C}$ para posterior transformação.

\subsubsection{Transformação de células competentes de Escherichia coli com os fragmentos}

A metodologia de transformação de fragmentos inteiros e fragmentos sonicados foi a mesma. Um volume de $10 \mu \mathrm{l}$ do produto da ligação foi adicionado a $100 \mu \mathrm{l}$ de células competentes da cepa $\mathrm{DH} 5 \alpha$ preparadas conforme Hanahan (1983), descongeladas em gelo por cinco minutos. Os tubos foram mantidos em gelo por 20 minutos e, a seguir, as células foram submetidas a um choque térmico a $42^{\circ} \mathrm{C}$ por 90 segundos e transferidas imediatamente para o gelo, onde foram mantidas por dois minutos. Em seguida, $900 \mu \mathrm{l}$ de meio SOC (1\% de triptona; $0,5 \%$ de extrato de levedura; $8,5 \mathrm{mM}$ de $\mathrm{NaCl} ; 2,5 \mathrm{mM}$ de $\mathrm{KCl} ; 0,01 \mathrm{mM}$ de $\mathrm{MgCl}_{2} ; 0,02 \mathrm{mM}$ de glicose, água q.s.p. $1000 \mathrm{~mL}$ ) foram adicionados æ̀s células transformadas que foram então incubadas a $37^{\circ} \mathrm{C}$ por uma hora. As células foram centrifugadas rapidamente e 
$600 \mu \mathrm{l}$ do sobrenadante descartado. O precipitado foi ressuspendido e plaqueado em meio LB ( $1 \%$ de triptona; $0,5 \%$ de extrato de levedura; $0,25 \%$ de $\mathrm{NaCl} ; 4 \%$ de ágar) contendo $0,1 \mathrm{mM}$ de IPTG (isopropil-â-Dtiogalactopiranosida), $40 \mu \mathrm{g} / \mathrm{mL}$ de X-gal (5-bromo-4cloro-3-indolit-â-Dgalactopiranosida) e $10 \mu \mathrm{g} / \mathrm{ml}$ de ampicilina. As placas de petri foram incubadas a $37^{\circ} \mathrm{C}$ por 13 horas. Após esse período, as colônias recombinantes foram coletadas sob condições estéreis e inoculadas em $1 \mathrm{ml}$ de meio Circle Grow (Bio 101 Inc., Carlsbad, CA) contendo $100 \mu \mathrm{g}$ de ampicilina por ml de meio.

A extração dos plasmídeos para posterior seqüenciamento de seus insertos foi realizada em placas de crescimento de 96 amostras (Masterblock, Greiner Lab., Frickenhausen, AL.) pelo método da lise alcalina (Sambrook et al., 1989)

\subsubsection{Seqüenciamento}

A reação de seqüenciamento foi realizada com aproximadamente $200 \mathrm{ng}$ de DNA plasmidial, $2 \mu \mathrm{l}$ de mix do kit DYEnamic TM ET terminator cycle sequencing premix (Amersham Pharmacia Biotech Inc., Piscataway, NJ), 3,2 $\mu \mathrm{M}$ de oligonucleotídeo M13F ou M13R e água para completar volume de $10 \mu \mathrm{l}$. As condições de amplificação foram as seguintes: 30 ciclos de desnaturação a $95^{\circ} \mathrm{C}$ por 20 segundos, hibridização a $50^{\circ} \mathrm{C}$ por 15 segundos e extensão a $60^{\circ} \mathrm{C}$ por um minuto. As reações foram realizadas em termociclador PTC 100 (MJ Research Inc., Watertown, MA). 
A precipitação dos dNTPs não incorporados foi realizada em placas de acordo com o protocolo do fabricante. O seqüenciamento foi realizado por eletroforese em gel de poliacrilamida 4\% em aparelho ABI Prism 377 DNA Sequencer ${ }^{\mathbb{M}}$ (Applied Biosystems, Foster City, CA, EUA) a 1680 volts a $50^{\circ} \mathrm{C}$, por dez horas, de acordo com o protocolo descrito pelo fabricante.

\subsubsection{Análise de polimorfismo e desenvolvimento de marcador CAPs}

Para análise de polimorfismo de comprimento entre os alelos $\mathrm{B}$ 16/RPS2 e Lc201/RPS2, as seqüências foram primeiramente analisadas com auxílio do programa Sequencher 3.0 (Gene Codes Corporation, Ann Arbor, MI) para identificar sítios de restrição. Os fragmentos B116/RPS2 e Lc201/RPS2 obtidos por PCR dos indivíduos parentais e $F_{1}$ foram então digeridos com as enzimas sugeridas pelo programa e com algumas enzimas que não apresentavam seus sítios de clivagem na seqüência para verificar a presença de erros nas seqüências. As seguintes enzimas foram utilizadas: Not I, Pme I, Pvu I, Xho I, Pst I, EcoR I, EcoR V, Xba I, Hpa II, BamH I, Taq I, Hind III, Alu I, Swa I. As reações contendo $1 \mathrm{x}$ do tampão da enzima, $10 \mathrm{U}$ da enzima de restrição e $8 \mu \mathrm{l}$ do produto de PCR foram incubadas por $6 \mathrm{~h}$ a $37^{\circ} \mathrm{C}$. Os fragmentos digeridos foram visualizados em gel de agarose $0,8 \%$. Fragmentos com tamanhos muito próximos foram separados por eletroforese em gel de agarose $2 \%$ durante 15 horas. 
A digestão com a enzima Xba I (Invitrogen Corp., Carlsbard, CA) revelou polimorfismo de comprimento entre os fragmentos B-16/RPS2 e Lc201/RPS2. Este polimorfismo obtido pela clivagem de fragmentos amplificados por PCR, "CAPs" (cleaved amplified polimorphisms) foi usado como marcador molecular em indivíduos da população $F_{2}$ conforme descrito a seguir.

\subsubsection{Análise da segregação entre marcador e gene de resistência a Xanthomonas campestris pv. campestris}

A análise empregada para verificar a presença de ligação entre 0 genótipo obtido pelo padrão de restrição com a enzima Xba I e genes que controlam a resistência a Xanthomonas campestris pv. campestris avaliados pela área foliar lesionada em $\mathrm{cm}^{2}$ (AFL) foi feita por meio de análise de variância. O genótipo no loco marcador foi considerado variável independente e a AFL como variável dependente. Se houver diferença significativa, a interpretação é de que existe ligação entre o marcador e gene que controla a característica avaliada. As análises foram feitas pelo programa Statistica versão 5.0 (StatSoft, EUA).

\subsubsection{Expressão do homólogo BI-16/RPS2 em Brassica oleracea}

\subsubsection{Amplificação por RT-PCR}

Plantas da linhagem resistente B B16 e suscetível Lc201, foram inoculadas com isolado PHW 1205 de X. c. pv. campestris aos 15 dias após 
germinação por meio de corte na extremidade da folha conforme Malvas et al. (1999).

Para extração do RNA mensageiro, a coleta do tecido foi realizada 24, 48, 72, 96 e 120 horas após a inoculação. Tecido foliar foi coletado e congelado em $\mathrm{N}$ líquido. $\mathrm{O}$ tecido foliar foi mantido em freezer $-80^{\circ} \mathrm{C}$ até a extração do RNA mensageiro. O RNA mensageiro foi extraído seguindo protocolo do Oligotex Direct mRNA midi kit (Qiagen GmbH, Hilden, Germany). A concentração de RNA mensageiro foi estimada por espectrofotômetro (Ultrospec 3100 pro, Amersham Pharmacia Biotech, Cambridge, UK).

O DNA complementar (DNAc) foi sintetizado com aproximadamente $3 \mu \mathrm{g}$ de RNAm. Inicialmente, o RNA foi incubado com $0,1 \mu \mathrm{M}$ de Oligo dT a $70^{\circ} \mathrm{C}$ por 10 minutos. Em seguida os tubos foram mantidos em gelo por cinco minutos. As amostras receberam $1 \mathrm{x}$ de tampão da enzima, 0,1 $\mu \mathrm{M}$ de DTT, 0,5 mM de dNTPs e 5 U da enzima RT/Platinum do kit Superscript One Step RT-PCR com Platinum Taq (Life Technologies Inc. Galthersburg). A síntese da primeira fita ocorreu a $45^{\circ} \mathrm{C}$ por 50 minutos. Após a reação a enzima RT/Platinum foi inativada por incubação a $70^{\circ} \mathrm{C}$ por 15 minutos.

Iniciadores específicos desenhados entre as bases 425 e 950 da seqüência nucleotídica do fragmento Bl-16/RPS2 foram utilizados para amplificar um fragmento de 500 pares de bases. Os oligonucleotídeos escolhidos foram $\quad{ }^{\prime}$-CCGCATTTAGTGACTATGG- ${ }^{3} \quad$ (direto) e ${ }^{5}$ GCAGAGCATTAACAACGA-3' (reverso). 
As reações de amplificação foram feitas com $10 \mu \mathrm{l}$ da amostra do DNAc, $1 \mu \mathrm{l}$ de tampão de PCR, $2 \mathrm{mM}$ de $\mathrm{MgCl}_{2}, 0,2 \mathrm{mM}$ de dNTP, 0,25 ì M de cada oligonucleotídeo e 1,25 U da enzima Taq DNA polimerase (Amersham Pharmacia Biotech, Piscataway, NJ). O programa de amplificação foi composto por um ciclo de dois minutos a $93^{\circ} \mathrm{C} ; 35$ ciclos de 45 segundos a $93^{\circ} \mathrm{C}, 45$ segundos a $51^{\circ} \mathrm{C}$ e um minuto a $72^{\circ} \mathrm{C}$; e uma extensão final a $72^{\circ} \mathrm{C}$ por dez minutos. Os produtos da reação foram separados em gel de agarose $1 \%$ (Promega Inc., Madison, WI) em TBE 0,5x. O gel foi corado em uma solução $0,5 \mathrm{ì} \mathrm{g} / \mathrm{ml}$ de brometo de etídio e o produto de amplificação visualizado por luz ultravioleta. Para detectar presença de DNA nas amostras, alíquotas de RNA foram usadas na reação de PCR como controle negativo.

\subsubsection{Clonagem do fragmento homólogo obtido a partir de DNAC de BI-16}

Para confirmação da expressão do homólogo, o fragmento obtido a partir de DNAc da linhagem Lc201 foi seqüenciado. As reações de ligação com o kit pGEM-T Easy Vector Systems (Promega, Madison, WI) e transformação foram feitas conforme descrito nos itens 3.1.2.2 e 3.1.2.4, respectivamente.

\subsubsection{Northern Blot}

$\mathrm{Na}$ análise de Northen blot, amostras de RNA foram submetidas a eletroforese conforme protocolo de Sambrook et al. (1989). Para marcação da sonda, foi utilizado o fragmento interno previamente amplificado na linhagem B $\mathrm{F}$ 16 (item 3.1.6.2). A marcação da sonda foi realizada com o kit PCR Dig Probe 
Synthesis (Roche Diagnostics, Mannhein, Germany). Os iniciadores específicos (item 3.1.6.1) foram utilizados para amplificar o fragmento de 520 pares de bases a partir de 100ng de DNA plasmidial. Os demais reagentes foram utilizados conforme indicação do kit.

Para amplificação foram utilizadas as seguintes condições: um ciclo de dois minutos a $95^{\circ} \mathrm{C}, 30$ ciclos de 30 segundos a $95^{\circ} \mathrm{C}, 30$ segundos a $60^{\circ} \mathrm{C} \mathrm{e}$ um ciclo de 40 segundos a $72^{\circ} \mathrm{C}$, e uma extensão final a $72^{\circ} \mathrm{C}$ por sete minutos. Os produtos de PCR foram separados em gel de agarose 1\% (Promega Inc., Madison, WI) em TBE 0,5X.

Para controle positivo da hibridização foi utilizado um fragmento amplificado com oligonucleotídeos baseados no gene da $\beta$-actina de $B$. oleracea. O produto de PCR foi diluído para as concentrações de $10 \mathrm{ng}, 1 \mathrm{ng}$, 100 pg e 1 pg de DNA, desnaturado e fixado em membrana de naylon. Este mesmo fragmento foi utilizado como sonda para controle da hibridização. A transferência para membrana seguiu protocolo de Sambrook et al. (1989). A hibridização foi feita de acordo com o kit Dig Easy Hybe e a detecção de acordo com 0 kit Dig Labelling and Detection (Roche Diagnostics, Mannhein, Germany). 


\subsection{Clonagem e caracterização genética de fragmentos homólogos a genes de resistência em Zea mays}

\subsubsection{Material vegetal}

Para realização do trabalho com Zea mays, foram utilizadas seis linhagens (AG41, AG45, DAS4, DAS6, DAS21, DAS95) e quatro híbridos (AG41 x AG45, DAS4 x DAS6, DAS21 x DAS6, DAS95 x DAS21). As linhagens AG41

e AG45 são resistente e suscetível, respectivamente, a Exserohilum turcicum. As linhagens DAS4 e DAS6, são resistente e suscetível, respectivamente, a Colletotrichum graminicola causador da antracnose foliar. As linhagens DAS21 e DAS6 são resistente e suscetível, respectivamente, a Colletotrichum graminicola causador da podridão de colmo em milho. As linhagens DAS95 e DAS21, são resistente e suscetível, respectivamente, a Phaeosphaeria maydis causador da mancha de phaeosphaeria.

\subsubsection{Clonagem de homólogos a genes de resistência em Zea mays}

\subsubsection{Amplificação dos fragmentos homólogos a genes de resistência}

A extração de DNA vegetal foi feita conforme descrito no item 3.1.2

Para amplificação de fragmentos homólogos em Zea mays, oligonucleotídeos específicos nos sentidos direto e reverso foram sintetizados com base nas seqüências denominadas Pic17 e Pic18 disponíveis no GenBank 
sob números gi|3982625 e gi|3982627, respectivamente. Com o auxílio do programa PRIMER 3 (http://www.genome.wi.mit.edu//cgi-bin/primer/primer3.cgi) foram escolhidos os seguintes oligonucleotídeos: Pic17F ${ }^{5-}$

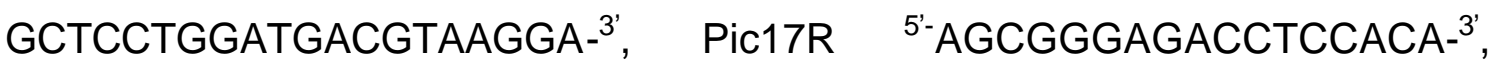
Pic18F 5'-GGATGACGTCTGGAATAGGG-3' e Pic18R 5'GCAAAACATTGCTTCATGTCA- ${ }^{3}$.

As reações de amplificação ocorreram com $5 \mu$ de tampão da enzima, $2 \mathrm{mM}$ de $\mathrm{MgCl}_{2}, 0,1 \mathrm{mM}$ de dNTP, $1 \mathrm{U}$ de Taq DNA Polimerase (Promega, Madison, WI) e 0,25 mM de cada oligonucleotídeo. O volume final da reação foi de $50 \mu \mathrm{L}$. As condições de amplificação com o oligonucleotídeo Pic17 foram as seguintes: $93^{\circ} \mathrm{C}$ por dois minutos, seguidos de 35 ciclos de $93^{\circ} \mathrm{C}$ por 45 segundos, $51^{\circ} \mathrm{C}$ por 45 segundos, $72^{\circ} \mathrm{C}$ por um minuto e um ciclo de extensão final por 10 minutos a $72^{\circ} \mathrm{C}$. Para amplificação com o oligonucleotídeo Pic18, foi utilizada temperatura de hibridização de $58^{\circ} \mathrm{C}$.

\subsubsection{Amplificação de fragmentos homólogos a ESTs}

Para obtenção dos oligonucleotídeos baseados em ESTs, foram feitas buscas no banco "maize dBase" (www.agron.missouri.edu/ests) com as palavras "pathogen" e "disease resistance". As seqüências foram analisadas e classificadas quanto à similaridade por meio do algoritmo BLAST (Altschul et al., 1997). 
As seqüências dos ESTs foram alinhadas pelo programa Sequencher 3.0 (Gene Codes Corporation, Ann Arbor, Mi). A seqüência consenso daquelas que agruparam entre si utilizando os parâmetros $85 \%$ de similaridade e 20 bases de sobreposição foi utilizada para construção de oligonucleotídeos pelo programa Primer 3 (www-genome.wi.mit.Edu/cgi-bin/primer). Foram construídos oligonucleotideos para as classes representativas dos ESTs: PR4, LRR, quitinases, resistência a Fusarium, Cf2 e Cf5, PR1 e "putative disease resistance".

Para amplificação, inicialmente foram testadas diferentes temperaturas de anelamento para cada conjunto de iniciadores. As condições básicas de amplificação foram as seguintes: $93^{\circ} \mathrm{C}$ por dois minutos, seguidos de 35 ciclos de $93^{\circ} \mathrm{C}$ por 45 segundos, temperatura de anelamento variável entre 51 e $59^{\circ} \mathrm{C}$ por 45 segundos, $72^{\circ} \mathrm{C}$ por um minuto e um ciclo de extensão final por 10 minutos a $72^{\circ} \mathrm{C}$. A reação foi a seguinte: $5 \mu \mathrm{l}$ de tampão da enzima, $2 \mathrm{mM}$ de $\mathrm{MgCl}_{2}, 0,1 \mathrm{mM}$ de dNTP, 1,5 U de Taq DNA Polimerase (Promega, Madison, WI) e $0,25 \mu \mathrm{M}$ de cada oligonucleotídeo. O volume final da reação foi de $50 \mu \mathrm{L}$. Os fragmentos foram resolvidos em gel de agarose $1 \%$.

\subsubsection{Análise de polimorfismo}

Os produtos de PCR obtidos da amplificação de DNA dos indivíduos parentais e híbridos foram digeridos com as enzimas de restrição Xba I (Invitrogen, Rockeville, MD), EcoR I, EcoR V, Pst I, Pvu I, Xho I, Hind III, BamH 
I (Amersham Pharmacia Biotech, Piscataway, NJ) e Alu I (Promega Incorporation, Madison, WI). As reações contendo $2 \mu \mathrm{l}$ de tampão da enzima, 10 $U$ da enzima de restrição e $8 \mu l$ do produto de PCR foram incubadas por 8 horas a $37^{\circ} \mathrm{C}$. Os fragmentos foram visualizados em gel de agarose $2 \%$ com tampão TBE 1x. 


\section{RESULTADOS}

4.1 Clonagem e caracterização genética de um fragmento homólogo ao gene RPS2 em Brassica oleracea

\subsubsection{Clonagem do homólogo ao gene RPS2}

\subsubsection{Amplificação dos fragmentos Bl-16/RPS2 e Lc201/RPS2}

Os oligonucleotídeos baseados no gene RPS2 amplificaram um fragmento de aproximadamente 2.500 pares de bases na linhagem parental resistente a Xanthomonas campestris pv. campestris, Badger Inbred-16 e na linhagem suscetível, Lc201. Estes fragmentos foram denominados de B 16/RPS2 e Lc201/RPS2, respectivamente (Figura 1). 


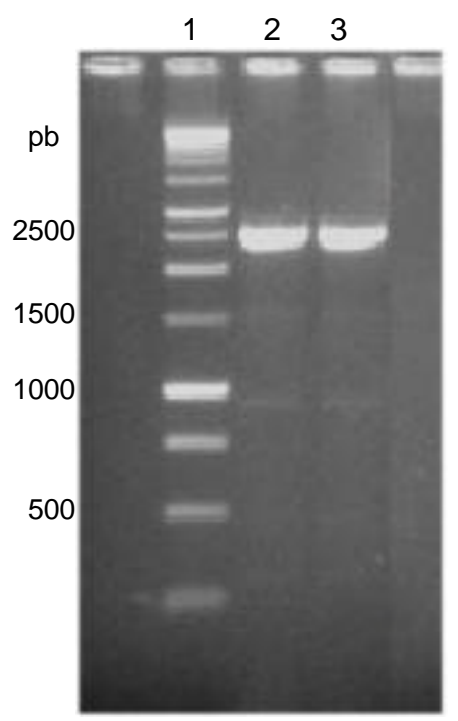

Figura 1 - Fragmentos de 2,5 Kb amplificados com os oligonucleotídeos B1F e B1R nas linhagens Bt16 e Lc201. 1: marcador de peso molecular 1Kb Ladder (Promega, Madison, WI); 2: linhagem BH16; 3: linhagem Lc201.

\subsubsection{Seqüenciamento dos fragmentos BI-16/RPS2 e Lc201/RPS2}

Os fragmentos amplificados nas linhagens resistente e suscetível foram sequenciados e analisados. As seqüências "shotgun" do fragmento Br16/RPS2 foram alinhadas pelo programa Sequencher 3.0 e geraram uma seqüência consenso de 2506 pares de bases. Também foram alinhadas duas seqüências obtidas pelo seqüenciamento das extremidades $5^{\prime}$ e 3 ' do fragmento $\mathrm{B}$ 16/RPS2. Estas seqüências identificaram os oligonucleotídeos anverso e reverso nas extremidades. De maneira similar, as seqüências do fragmento Lc201/RPS2 geraram uma seqüência consenso de 2522 pares de bases. A 
comparação entre as seqüências de ambos os fragmentos revelou similaridade de 95 \% e a presença de 112 substituições de nucleotídeos, que corresponde a aproximadamente $4,4 \%$, e a presença de 12 inserções ou deleções, que correspondem a $0,7 \%$ de nucleotídeos (Figura 2). No alinhamento estão demonstrados os sítios de restrição da enzima Xba I. É possível observar que os sítios de restrição ocorreram dentro das regiões identificadas como os domínios conservados NBS e LRR.

A análise das seqüências consenso de ambos os fragmentos por meio do algoritmo BLAST (Basic Local Alignment Search Tool) (Altschul et al., 1997) revelou alta similaridade com mais de 40 seqüências do gene RPS2 de diferentes espécies do gênero Brassica, bem como de vários ecotipos de Arabidopsis thaliana e outras espécies (Tabela 1). A seqüência de Lc201/RPS2 revelou homologia com outras seqüências além daquelas descritas na tabela 1. Entre elas, com o gene RPS2 de Brassica napus cultivar Drakkar (AF181727) (96\% de homologia, Valor E 0,0) e com o gene homólogo ao RPS2 de um cultivar "rapid cycling" de B. oleracea (AF181729) (96\% de homologia, valor E $0,0)$. 
Tabela 1. Porcentagem de homologia, dados pela razão entre nucleotídeos idênticos e número total de nucleotídeos e nível de significância (valor-E) para as comparações entre as seqüências BI-16/RPS2 e Lc201/RPS2 e seqüências depositadas no banco de dados do NCBI.

\begin{tabular}{|c|c|c|}
\hline Seqüências & $\%$ Homologia & Valor E \\
\hline RPS2 de Brassica montana (AF 180358) & 98 & 0.0 \\
\hline RPS2 de B. oleracea do ecotipo B117 (AF180357) & 98 & 0.0 \\
\hline $\begin{array}{l}\text { RPS2 do ecotipo B265 ABl1, N-myristoyl transferase e } \\
\text { proteína CK1a de B. oleracea (AF180355) }\end{array}$ & 98 & 0.0 \\
\hline RPS2 de B. rapa (AF180359) & 95 & 0.0 \\
\hline RPS2 de B. nigra (AF180360) & 92 & 0.0 \\
\hline RPS2 de Erucastrum laevigatum (AF180361) & 91 & 0.0 \\
\hline $\begin{array}{l}\text { RPS2 do ecotipo Kas-1 de Arabidopsis thaliana } \\
\text { (AF487814.1) }\end{array}$ & 88 & 0.0 \\
\hline RPS2 de A. lyrata (AF487796.1) & 86 & 0.0 \\
\hline RPS2 do ecotipo Pog-0 de $A$. thaliana (AF487817.1) & 88 & 0.0 \\
\hline RPS2 do ecotipo Ct-1 de A. thaliana (AF487816.1) & 88 & 0.0 \\
\hline
\end{tabular}


$\mathrm{Na}$ região da extremidade 5' do motivo rico em leucina (LRR), a seqüência nucleotídica BH16/RPS2 apresentou 100\% de identidade com o gene homólogo ao RPS2 descrito no ecotipo B117 de B. oleracea e $88,5 \%$ de identidade com o RPS2 de $A$. thaliana. Nesta mesma região, a identidade entre o RPS2 de B117 e de A. thaliana foi de 88\% (Wroblewski et al., 2000). 
BI- $16 /$ RP S 2 LC2 01 / RPS 2

BI-16/RP S 2 LC2 01 / RPS 2

BI- $16 /$ RP S 2 LC2 01 / RP S 2

BI $-16 / R P S 2$ LC2 $01 / R P S 2$

BI $-16 /$ RP S 2 LC2 01 / RPS 2

BI- $16 /$ RP S 2 LC201/RPS 2

BI $-16 /$ RP S 2 LC2 01 / RPS 2

BI $-16 /$ RP S 2 LC2 01 /RPS 2

BI- $16 /$ RP S 2 LC2 $01 / R P S 2$

BI $-16 /$ RP S 2 LC2 01 / RP S 2

BI $-16 /$ RP S 2 LC2 01 / RPS 2

BI- $16 /$ RP S 2 LC2 01 / RPS 2

BI $-16 /$ RP S 2 LC 201 / RPS 2

BI $-16 / R P S 2$ LC201/RPS 2

BI-16/RP S 2 LC2 01 / RP S 2

BI $-16 /$ RP S 2 LC2 01 /RPS 2

BI $-16 /$ RP S 2 LC2 01 / RP S 2

BI $-16 /$ RP S 2 LC2 01 / RPS 2

BI $-16 /$ RP S 2 LC201/RPS 2

BI $-16 /$ RP S 2 LC2 01 / RPS 2

BI $-16 /$ RP S 2 LC201/RPS 2

BI-16/RPS 2 LC2 01 / RPS 2

BI $-16 /$ RP S 2 LC201/RPS 2
AAGCCATCAGTCATCTCGAAACAGCCACAGGTCAACTGAAGGCCATACGTCACGACCTGA 60 AAGCCATCAGTGATCTCGAAACAGCCACAGGTGAACTGAAGGCCATACGTGACGACCTGA 60

ATCTACGCATCCAACGAGACAATATAGAGGGTCGAAGCTGCACAAACCGTGCCAGAGAGT 120 ATCGACGCATCCAACGAGACAATCGAGAGGGTCGAAGCTGCACAAACCGTGCCAGAGAGT 120

GGCTCAGTGCGGTGCAAGCAGCAGAGGTAAGAACAGAATCAATTCTAGCGAGGTTTATGC 180 GGCTCAGTGCGGTGCAAGCAGCAGAGGTAAGAACAGAATGAATTCGAGCAAGGTTTATGC 180

GTCGGGAACAGAGGAAGATGATGCAGAGGAGATGCCTTCGTTGCTTAGGTTGTGCTTCAT 240 GTCGGGAACAGAAGAAGATGATGCAGAGGAGATGCCTTAGTTGCTGAGGTTGTGCTGAAT 240

ACAAACTGAGCAAGAAGG-TTTTGGGGTCACTGAAGAGTATCAATCAGCTGA-GACAAC- 297 ACAAACTGAGCAAGAAGGGTTTTGGGGTCACTGAAGAGTATGAATGAGCTGAAGACAACC 300

GCTCTTTA-GATATACAAACAGATGGCGGGTTGATTCAAGAGACTTGTACGAAGATACCT 356 GCTCTTGAAGATATACAAACAGATGGCGGGTTGATTGAAGAGACTTGTACGAAGATACCT 360

ACCAATCTCTCGATTGGGATTACAACAATTAAGAACAGGTGTGGGAACTTTTCAgTCAA 416 ACCAAGTCCGTGGTTGGGATTACA-CAATTdTAGAACAGGTG-GGGAACTTCTGAGTGAA 418

GAAGAAGAAAGAGGAATCATTGGTGTTTATGGACCTGGCGGGGTTGGGAAGACAACGTTA 476 GAAGAAGAAAGAGGAATCGTTGGTGTTTATGGACCTGGCGGGGTTGGGAAGACAACGTTA 478

ATGCAGAGCATTCACAACGAGCTGATCACAAAAGgTCATCAGTACGATGTACTGATATGG 536 ATGCAGAGCATGAACAACGAGCTGATGACAAAAGGTCATCAGTACGATGTACTGATATGG 538

GTTACAATGTCCCGTCAATTCGGAGAGTGTACAATTCAACAAGCTGTTGGAGCGCGGTTG 596 GTTGCAATGTCCCGTGAATTCGGAGAGTGTACAATTCAGCGAGCTGTTGGAGCGCGGTTG 598

GGTTTATCTTGGGATCAGAAGGAGACAGGGGAAGGTCGAGCTTTCAGGATATACAGAGCT 656 GGTTTATCTTGGGATGAGAAGGAGACAGGGGAAGGTAGAGCTTTGAGGATATACAGAGCT 658

TTGAAACAGAGACGGTTCTTGTTGTTGCTTTATCATGTCTGGGAAGAGATAGACTTTCAG 716 TTGAAACAGAGACGGTTCTTGTTGTTGCTTGATGATGTCTGGAAAGAGATAGACTTTGAG 718

AAAACCGGTGTTCCTCGACCTCACAGGGAAAACAAATGCAAGATAATGTTCACAACACG- 775 AAAACCGGTGTTCCTCGACCTGACAGGGAAAACAAATGCAAGATAATGTTGACAACACGG 778

-TGTCTA-GACATTATGCAGCAACATTGGTdTAGAATGCAAGCTGAGAGTGGAGTTTCTG 833 TCGTCTCTGGCATTATGCAGCAACATTGGTdTAGAATGCAAGCTGAGAGTGGAGTTTCTG 838

GAGAAGCAACACGCGTGGGAGCTCTTCTGTGGTAAAGTTGGGAGAAGAGACCTCTTGGAG 893 GAGAAGCAACACGCGTGGGAGCTCTTCTGTGGTAAAGTTGGGAGAAGAGGCCTCTTGGAG 898

TCACCGTTGATTCGCCGGCACGCTGAGAACATAGTCACTAAATGCGGTGGATTGCCACTA 953 TCGCCGATCCTAAAGGGTCGGGGTGATGGCATAGTCGCGAAATGCGGTGGATTGCCACTA 958

GCGTTGATCACTTTAGGAGGAGCCATGGCTCACAGAGAGACTGAAGAGGAGTGGATTCAC 1013 GCGTTGATGACTTTAGGAGGAGCCATGGCTCACAGAGAGACTGAAGAGGAGTGGATTCAC 1018

-GCCAATGAAGTTCTGAATAGATTTCCAGCAGAGATGAAGGGTATGGACTATGTATTTGC 1072 TGCCAATGAAGTTCTGAATAGGTTTCCAGCAGAGATGAAGGGTATGGACTATGTATTTGC 1078

CCTTTTAAAATTCAGCTACGACAACCTCGAGAG----CGATCTGCTTCGAACTTGTTTCT 1128 CCTTTGAAAAT TCAGTTACGACAACCTCGAGAGAGAGCGATCCCCTTCGAACTTGTTTCT 1138

TGTACTGCGCTTTATTCCCAGAAGATCACTCTATTGAGATCGAACAGCTTGTTGAGTACT 1188 TGTACTGCGCTTTATTCCCAGAAAATCACTCTATTGAGATCGAACAGCTTGTTGAGTACT 1198

GGGTCGGAGAAGGGTTTCTGATCAGCTCCCATGGCGTTAACACTATATACCAGGGATATT 1248 GGGTCGGAGAGGGGTTTCTGATCAGCTCCCATGGCGTTAACACTATATACCAGGGATATT 1258

TTCTGGTTGGAGATCTTAAAGCGGCGTGTTTGTTGGAAACCGGAGATGAGAAGACGCAGG 1308 TTCTGGTTGGAGATCTTAAAGCGGCGTGTTTGTTGGAAACCGGAGATGAGAAGACGCAGG 1318

TGAAGATGCATAATGTCGTTAGAAGCTTTGCACTGTGGATGGCATCTGAACAGGGGACTT 1368 TGAAGATGCATAATGTCGTTAGAAGCTTTGCACTGTGGATGGCATCTGAACAGGGGACTG 1378 
BI-16/RPS 2 LC2 01 /RPS2

BI-16/RPS 2 LC2 01 /RPS 2

BI-16/RPS 2 LC2 01 / RPS 2

BI-16/RPS 2 LC201/RPS 2

BI-16/RPS 2 LC2 01 / RPS 2

BI-16/RPS 2 LC201/RPS 2

BI-16/RPS 2 LC201/RPS 2

BI-16/RPS 2 LC2 01 / RP S 2

BI-16/RPS 2 LC2 01 / RPS 2

BI-16/RPS 2 LC2 01 /RPS 2

BI-16/RPS 2

LC2 01 / RPS 2

BI-16/RPS 2 LC201/RPS2

BI-16/RPS 2 LC2 01 / RP S 2

BI-16/RPS 2 LC2 01 / RPS 2

BI-16/RPS 2 LC2 01 /RPS 2

BI-16/RPS 2 LC2 01 / RPS 2

BI-16/RPS 2 LC2 01 / RPS 2

BI-16/RPS 2 LC201/RPS 2

BI $-16 /$ RPS 2 LC2 01 / RPS 2

BI-16/RPS 2 LC201/RPS 2
ATAAGGAGCTGATCCTAGTAGAGCCAAGCATGGGACTTACTGGAGCTCCCAAAACAGAAA 1428 ATAAGGAGCTGATCCTAGTAGAGCCAAGCATGGGACTTACTGAAGCTCCCAAAACAGAAA 1438

GATGGCGACATACGTTGGTGATTTCGTTTTGGATAACAGACTCCAGATGTTGCCTGAAA 1488 GATGGCGACATACGTTGGTGATTTCGTTGTTGGATAACAGACTCCAGATGTTGCCTGAAA 1498

ATCCCATATGCCCGAATCTGACAACATTGCTGCTCCAGCAGAACAGCTCTTTGAAGAAGA 1548 ATCCCATATGCCCGAATCTGACAACATTGCTGCTCCAGCGGAACAGCTCTTTGAAGAAGA 1558

TtCCAGCAAACTTtTICATGTATATGCCTGTtCTCAGGGTCCTTGACTtGTCCTTCACAA 1608 TTCCAACAAACTTTTTCATGTATATGCCTGTTCTCAGGGTCCTTGACTTGTCCTTCACAA 1618

GTATCACTGAGATCCCACTGTCTATTAAGTATTTGGTGGAGTTGTATCATCTAGCTCTGT 1668 GTATCACTGAGATCCCACTGTCTATTAAGTATTTGGTGGAGTTGTATCGTCTAGCTCTGT 1678

CGGGAACAAAGATAAGTGTGCTGCCTCAAGAGCTTAGGAATCTTAGAATGCTGAAGCATC 1728 CGGGAACAAAGATAAGTGTGCTGCCTCGAGAGCTTGGGAATCTTAGAATGCTCAAGCATC 1738

TAGACCTACAAAGAACGCAGTTTCTCCAGACAATCCCACGAGATGCCATATGTTGGCTAA 1788 TAGACCTACAAAGAACGCAGTTTCTCCAGACAATCTCACGAGATGCCATATGTTGGCTAA 1798

GCAAGCTCGAGG---TTCTGAACCTATACTACAGTTACGCTGGTTGGGAACTGCAGAGCT 1845 GCAAGCTCGGGGAATCTATAGGGTCGTGCAACAGTGACGCTGGTTGGGAACTGCAGAGCG 1858

ATGGAGAAGATGAAGAAGAAGA-ACTTGGATTTGCCGACCTGGAACACTTAGAAAACCTC 1904 ATGGAGAAAATGAAGAAGAAGACACTTGGATTTGCCGACTTGGAACACTTAGAAAACCTG 1918

ACCACACTCGGTATCACTGTTCTCTCACTGGAGAGCCTGAAAACACTCTACGAGTTTGAC 1964 ACCACACTCGGTATGACTGTTCTCTCACTGGAGAGCCTGAAAACACTCTACGAGTTTGAC 1978

GTCTTGCATAAATGTATACAGCATCTGCACGTTGAAGAATGCAATGGTCTCCCCCACTTC 2024 GCCTTGCATAAATGTATACAGCATCTGCATGTTGAAGAATGCAATGGTCTCCCCCACTTC 2038

GATCTCTCATCACTCTCAAACCACGGTGGGAACATAAGAAG CTAGACATTAAAAGTTGC 2084 GATCTCTCATCACTCTCAAACCACGGTGGGAACTTA AGAAG] CTAGACATTAAAAGTTGC 2098

AATGACTTGGAGTACCTGATCACACCTACAGATGTTGATTGGCTTCCAAGTCTAGAGGTT 2144 CATGACTTGGAGTACCTGGTGACACCCACAGATGTTGATTGGCTTCCCAGTCTAGAGGTT 2158

CTGACGGTACACAGCCTCCACAAGTTAAGCAGAGTGTGGGGAAATTCTGTAAGCCAAGAG 2204 CTGACGGTACACAGCCTCCACAAGTTAAGCAGAGTGTGGGGAAATTCTGTAAGCCAAGAG 2218

AGTCTGCGGAACATCCGTTGCATCAACATTTCACACTGCC CAAGCPCTAGAACGTCTCA 2264 AGTCTGCGGAACATCCGTTGCATGAACATTTCACACTGCCLCAAGCFCTAGAACGTCTCA 2278

TGGGCTCAGCAACTCCCAAAGCTAGAGACGATTGACCTGTTCGACTGCAGAGAGCTAGAG 2324 TGGGCTCAGCAACTCCCAAAGCTAGAGACGATTGACCTGTTCGACTGCAGAGAGCTAGAG 2338

GAACTGATTAGTGATCTAGAGAGTCCATCCATTGAAGATCTAGTATTGTTCCCAGGCCTG 2384 GAACTGATGAGTGACCATGAGAGTCCATCCATTGAAGATCTAGTATTGTTCCCAGGCCTG 2398

AAGACTTTGTCAATTAGGGATCTACCAGAACTAAGCAGCATCCTTCCATCTCGATTTTCT 2444 AAGACTTTGTCAATTAGGGATCTACCAGAACTAAGCAGCATCCTTCCATCTCGATTTTCT 2458

TTCCAGAAACTAGAAACTTTAGTCATCATAAATTGCCCCAAAGTGAAGAAACTGCCATTT 2504 TTCCAGAAACTAGAAACTTTAGTGATGATAAATTGCCCCAAAGTGAAGAAACTGCCATTT 2518

CA 2506

CA 2520

Figura 2 - Alinhamento entre as seqüências BI-16/RPS2 e Lc201/RPS2. Regiões em caixas são sítios de Xbal. Regiões sublinhadas em preto correspondem ao domínio NBS e em vermelho ao LRR. 
As fases de leitura foram preditas por meio do programa ORFinder do National Center for Biotechnology Information (www.ncbi.nlm.nih.gov). Na seqüência de BI-16/RPS2 foi identificada uma fase de leitura situada entre os nucleotídeos 177 e 2506, com uma possível alteração no quadro de leitura (frameshift) no nucleotídeo 782. Com base na seqüência de Lc201/RPS2, o programa identificou três possíveis fases de leitura. A primeira situada entre os nucleotídeos 473 e 1357, a segunda entre os nucleotídeos 1730 e 2520 e a terceira entre 1069 e 2520 com um possível "frameshift" no nucleotídeo 909. A seqüência de aminoácidos foi analisada quanto a similaridades por meio dos programas BLASTX e TBLASTX. As seqüências revelaram identidade de seqüência média de $80 \%$ com 100 seqüências de proteínas relacionadas a genes de resistência a doenças de plantas depositadas no banco de dados do NCBI (RPS2 de B. oleracea, AAF19803.1; RPS2 de A. thaliana, AF 487814.1; NBS-LRR de A. thaliana, AF506028.19; RPR1 de Oryza sativa, BAA75812.1; complexo I2C-2, TO6404). O alinhamento entre a seqüência de aminoácidos do fragmento Bl-16/RPS2 e Lc201/RPS2 e do RPS2 de $A$. thaliana e de $B$. oleracea revelou regiões de alta homologia (Figura 3). Dentro da região NBS compreendida entre os aminoácidos 182 e 335 foram detectados 23 substituições de nucleotídeos (15\%) e duas inserções (1,3\%) entre a seqüência de Bl-16/RPS2 e RPS2 de $A$. thaliana. Para a região LRR, entre os aminoácidos 505 e 867 do RPS2 de A. thaliana, foram detectadas 44 mutações $(12,1 \%)$ e 2 inserções $(0,5 \%)$. 
A seqüência de nucleotídeos foi analisada quanto à presença de domínios funcionais usando o programa PROSITE (Hoffmann et al., 1999) disponível na internet no site http://bo.expasy.org/prosite. A proteína derivada do fragmento BH16/RPS2 possui um sítio de Nmiristoilação e um grande número dos aminoácidos alanina, cisteína, glicina e treonina típicos de proteínas com função de adição do carboidrato miristato à porção $\mathrm{N}$-terminal da proteína durante sua conformação. Proteínas miristoiladas freqüentemente, mas não sempre, estão associadas àmembrana (Lewin, 2000). 
BI-16/RPS2

B117

LC2 01 / RP S 2

RP S 2

BI $-16 /$ RPS 2

B117

LC2 01 / RPS 2

RPS2

BI-16/RPS

B117

$\mathrm{LC} 201 / \mathrm{R} 2$

RP S 2

BI-16/RPS

B117

LC2 01 / RPS

RPS 2

BI-16/RPS2

B117

LC2 01 /RPS

RP S 2

BI-16/RPS 2

B117

LC2 01 / RPS 2

RP S 2

BI-16/RPS2

B117

LC2 01 / RPS 2

RPS 2

BI-16/RP S 2

B117

LC2 01 / RPS 2

RP S 2

BI-16/RPS 2

B117

LC201/RPS2

RP S 2

BI-16/RPS2

B117

LC201/RPS2

RPS 2

BI-16/RPS2

B117

LC2 01 / RPS 2

RP S 2

BI-16/RPS2

B 117

LC2 01 / RPS 2

RPS2

BI-16/RPS 2

B117

LC201/RPS2

RP S 2

BI $-16 /$ RPS 2

$\mathrm{B} 117$

LC2 01 / RPS 2

RPS 2

BI $-16 /$ RPS 2

B117

LC201/RPS 2

RPS 2
MDCISSLVVGLAQALCESMNMAERRAGHKTDLKQAISDLETATGELKAIRDDLNLRIQRD 60 MDFISSLIVGCAQVLCESMNMAERRG-HKTDLRQAITDLETAIGDLKAIRDDLTLRIQQD 59

NIEGRSCTNRAREWLSAVQAAEVRTESILARFMRREQRKMMQRRCLRCLGCASYKLSKK- 85 NLEGRSCTNRAREWLSAVQAAEVRTES I LARFMRREQKKMMQRRC LSCLGCAEYKLSKK- 119 NREGRSCTNRAREWLSAVOAAEVRTE-IRARFMRREOKKMMORRCLSCG-CAEYKLSKKG 84 GLEGRSCSNRAREWLSAVQVTETKTALLLVRFRRREQRTRMRRRYLSCFGCADYKLCKK- 118

-GARRVLGSLKKINQLRQRSLD-IQTDGGLIQETCTKIPTNLSIGITTMMEQVWELFSQE 139 FGARRVIGSLKS INELRORSED-IOTDGGITOETCTKIP TKSVVGITTMMEOVWELLSEE 173 FGARRVLGSLKSMNELKTTALEDIQTDGGLIEETCTKIPTKSVVGIT-------ELLSEE 137 FGARRVSAILKS I GELRERSEA-IKTDGGS IQVTCRE I I KSVVGNTTMMEQVLEFLSEE 172

EERGI I GVYGP GGVGKT T LMOS I HNE L ITKGHOYDVL IWVTMSROFGECTIQQAVGARLG 199 EERGI I GVY GP GGVGKTTLMQS INNELITKGHQYDVLIWVTMSREF GECTIQRAVGARLG 233 EERGIVGVYGP GGVGKTTLMOSMNNELMTKGHOYDVLIWVAMSREFGECTIORAVGARLG 197 EERGI I GVYGP GGVGKT T LMQS INNE LITKGHQYDVL IWVQMSREF GECTIQQAVGARLG 232

LSWDQKETGEGRAFRIYRALKQRRF LLLLYHVWEE IDF QKT GVPRP HRENKCKIMFTTR- 258 LSWDEKETGEGRAFR IYRALKORRF LLLLDDVWEE IDFEKTGVPRPDRENKCKIMFTTRF 293 LSWDEKETGEGRALRIYRALKQRRF LLLLDDVWKE IDFEKTGVPRPDRENKCKIMLTTRS 257 LSWDEKETGENRALKIYRALRQKRF LLLLDDVWEEIDLEKTGVPRPDRENKCKVMFTTRS 292

-VTLCSNIGAECKLRVEF LEKOHAWELFCGKVGRRDLLESPLIRRHAENIVTKCGGLPLA 317 -LALCSNIGAECKLRVEF LEKQHAWEFFCGKVGRRDF LESP LIRRHAENIVTKCGGLPLA 352 SLALCSNIGAECKLRVEF LEKQHAWELF CGKVGRRGLLESP I LKGRGD GIVAKCGGLP LA 317 -IALCNNMGAEYKLRVEF LEKKHAWELFCSKVWRKDLLESSS IRRLAE I IVSKCGGLP LA 351

LITLGGAMAHRETEEEWIHANEVLNRFPAEMKGMDYVFALLKFSYDNL--ESDLLRTCFL 375 IITLGGAMAHRETEEEWIHANEVLNRFPAEMKGMDYVFALLKF SYDNL--ESDLLRTCFL 410 LMTIGGAMAHRETEEFWIHANEVINRFPAEMKGMDYVFA-LKF SYDNLERESDPLRTCFI 376 LITLGGAMAHRETEEEWIHASEVLTRFPAEMKGMNYVFALLKF SYDNL--ESDLLRSCFL 409

YCALFPEDHSIEIEQLVEYWVGEGFLISSHGVNTIYQGYF LVGDLKAACLLETGDEKTQV 435 CALFPEDHSIEIEQLVEYWVGEGF LISSHGVNT IYQGYF LVGDLKAAC LVETGDEKTOV 470 YCALFPENHS IEIEQLVEYWVGEGF L ISS HGVNT IYQGYF LVGDLKAACLLETGDEKTQV 436 YCALFPEEHS IEIEQLVEYWVGEGF LTSSHGVNT IYKGYF L I GDLKAACLLETGDEKTQV 469

KMHNVVRSFALWMASEQGTYKELILVEP SMGLTGAPKTERWRHTLVISLLDNRLQMLPEN 495 KMHNVVRSFALWMASEQGTYKELILVEP SMGLTEAPKTERWRHTLVISLLDNRLQMLPEN 530 KMHNVVRSFALWMASEQGTDKELI LVEP SMGLTEAPKTERWRHTLVIS LLDNRLQMLPEN 496 KMHNVVRSFALWMASEQGTYKELI LVEP SMGHTEAPKAENWRQALVIS LLDNRIQTLPEK 529

P ICPNLTTLLLQQNSS LKKIPANFFMYMPVLRVLDLSFTSITEIPLSIKYLVELYHLALS 555 PICPNLTTLLLQONSS LKKIPANFFMYMPVLRVLDLSFTS ITEIPLS IKYLVELYHLALS 590 P ICPNLTTLLLQRNSS LKKIPTNFFMYMPVLRVLDLSFTSITEIPLSIKYLVELYRLALS 556 LICPKLTT LMLQQNSS LKKIP T GF FMHMPVLRVLD LSFTS ITEIP LS IKYLVELYHLSMS 589

GTKISVLPOELRNLRMLKHLDLORTOFLOTIPRDA ICWLSKL-EVLNLYYSYAGWELOSY 614 GTK I SVLPQELRNLRMLKH LD LQRTQF LQT I RDA ICWLSKL-EVLNLYYSYAGWELQSY 649 GTK I SVLPRE LGNLRMLKHLDLQRTQF LOT I SRDA I CWLSKLGES I GSCNSDAGWELOSD 616 GTKISVLPQELGNLRKLKHLDLQRTQFLQTIPRDAICWLSKL-EVLNLYYSYAGWELQSF 648

GEDEEE-ELGFADLEHLENLTTLGITVLSLESLKTLYEFDVLHKCIQHLHVEECNGLPHF 673 GEDEEE-ELGFADLEHLENLTTLGITVLSLESLKTLYEFDVLHKCIOHLHVEECNGLPHF 708 GENEKKKTLGFADLEHLENLTTLGMTVLSLESLKTLYEFDALHKCIOHLHVEECNGLPHF 676 GEDEAE-ELGFADLEYLENLTTLGITVLSLETLKTLFEFGALHKHIQHLHVEECNELLYF 707

DLSSLSNHGGNIRRLS IKSCNDLEYLITPTDVD--WLPSLEVLTVHSLHKLSRVWGNSVS 731 DLSSLSNHGGNIRRLS IKSCNDLEYLITPTDVD--WLPSLEVLTVHSLHKLSRVWGNSVS 766 DLSS LSNHGGNLRRLS I KS CHD LEYLVTP TDVD--WLP S LEVLTVHS LHKLSRVWGNSVS 734 NLPSLTNHGRNLRRLS IKSCHDLEYLVTPADFENDWLPSLEVLTLHS LHNLTRVWGNSVS 767

QESLRNIRCINISHCHKLKNVSWAQQLPKLETIDLFDCRELEELISDLESPSIEDLVLFP 791 QES LRN IRC INIS HCHKLKNVSWAQQLPKLETID LF DCRELEELISDHESP S IED LVLFP 826 QESLRNIRCMNISHCHKLKNVSWAQOLPKLETIDLFDCRELEELMSDHESPSIEDLVLFP 794 QDCLRNIRCINISHCNKLKNVSWVQKLPKLEVIELFDCREIEELISEHESP SVEDPTLFP 827

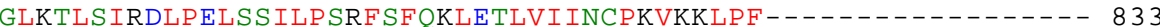
GIKTLSIRDLPELSSILPSRFSFOKLETLVI INCPKVKKLPFOER-VOPNLPAVYCDEKW 885 GLKTLSIRDLPELSS I LP SRF SF QKLETLVMINCP KVKKLPF------ - - - - - - - - 836 SLKTLRTRDLPELNSILPSRF SFQKVETLVITNCPRVKKLPFQERRTQMNLPTVYCEEKW 887 
BI $-16 /$ RP S 2

B 117

LC2 01 / RP S 2

RPS 2
WDALEKDQPITELCCSPRFVPN 907

WKALEKDQPNEELCYLPRFVPN 909

Figura 3 - Alinhamento entre seqüências de aminoácidos dos fragmentos $\mathrm{B}$ 16/RPS2, Lc201/RPS2, RPS2 de B117 (AF180357) e RPS2 de A. thaliana (ATU14158). Sublinhado em vermelho indica região NBS do gene RPS2. Sublinhado em preto indica região LRR.

\subsubsection{Análise de polimorfismo e segregação dos fragmentos BI-16/RPS2 e Lc201/RPS2}

Para análise de polimorfismo de comprimento entre os alelos dos dois parentais, as seqüências foram primeiramente digeridas eletronicamente. As enzimas sugeridas foram testadas nos fragmentos BH16/RPS2 e Lc201/RPS2 e no fragmento amplificado de um indivíduo $F_{1}$. Aquela que revelou polimorfismo foi utilizada como marcador em uma população $F_{2}$ segregante para resistência a Xanthomonas campestris pv. campestris, previamente avaliada para resistência a este patógeno (Camargo et al., 1995; Malvas et al., 1999).

As enzimas Pstl, EcoRl, EcoRV e Xbal apresentaram sítios de restrição mas, dentre estas, apenas a enzima Xbal (TCTAGA) revelou polimorfismo de comprimento entre os fragmentos BH16/RPS2 e Lc201/RPS2, confirmando o padrão esperado pela digestão eletrônica da seqüência nucleotídica. Segundo esta análise, a digestão de BH16/RPS2 deveria gerar cinco fragmentos de 389, 393, 1564, 81 e 115 pares de base, respectivamente. A seqüência da linhagem Lc201, indicou a existência de três sítios de restrição que deveriam gerar quatro fragmentos de 393, 412, 1654 e 112 pares de base (Figura 4). No gel de 
agarose os fragmentos de 1564 bases de Bl16/RPS2 e 1654 de Lc201/RPS2 são facilmente visualizados enquanto os demais aparecem mais fracos (Figura 5).

Estudo de co-segregação foi efetuado entre o fenótipo área de lesão causada por $X$. c. pv. campestris e o padrão de restrição de cada indivíduo $F_{2}$. Dos 43 indivíduos resistentes, cinco apresentaram o padrão de restrição igual ao parental resistente BH16 e 7 padrão igual ao suscetível Lc201. Destes, 31 apresentaram o mesmo genótipo que o indivíduo $F_{1}$ que também é resistente. Entre aqueles indivíduos fenotipados como suscetível, oito apresentaram genótipo igual a Bl16/RPS2 (R) e 18 igual a Lc201 (S). Vinte e cinco destes apresentaram o mesmo genótipo que o híbrido $F_{1}$. $O$ fenótipo e 0 genótipo de cada indivíduo $F_{2}$ estão descritos a seguir (Tabela 2) e o padrão de restrição para alguns indivíduos está representado na Figura 6. Análise de variância demonstrou não haver ligação $(F=2,81 ; p>0,05)$ entre este marcador e QTLs (quantitative trait loci) de resistência a $X$. c. pv. campestris. Estes dados indicam que o fragmento homólogo aqui amplificado não faz parte da região genômica responsável pelo fenótipo de resistência a $X$. c. pv. campestris neste cruzamento. 


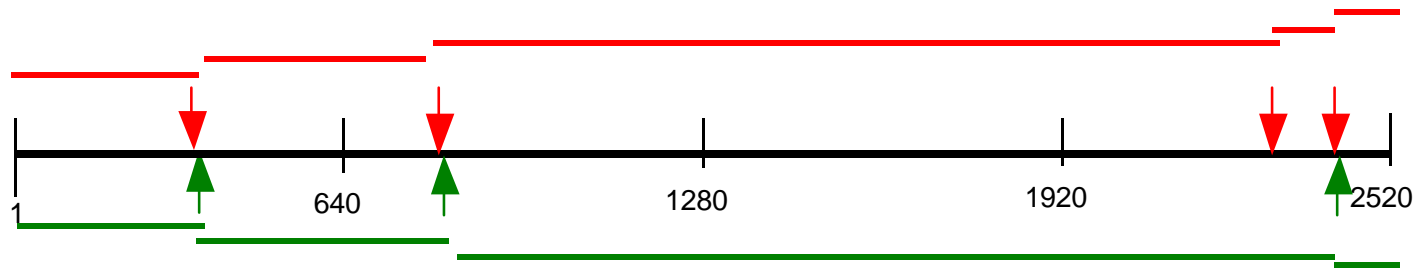

Figura 4 - Esquema representativo do corte da enzima Xba I na seqüência de BI-16/RPS2 e Lc201/RPS2. Barra preta representa os dois fragmentos. Setas e barras vermelhas correspondem aos sítios de restrição e tamanho dos fragmentos gerados em B116/RPS2, respectivamente. Setas e barras verdes correspondem aos sítios de restrição e tamanho dos fragmentos em Lc201/RPS2, respectivamente (Para detalhes, vide texto).

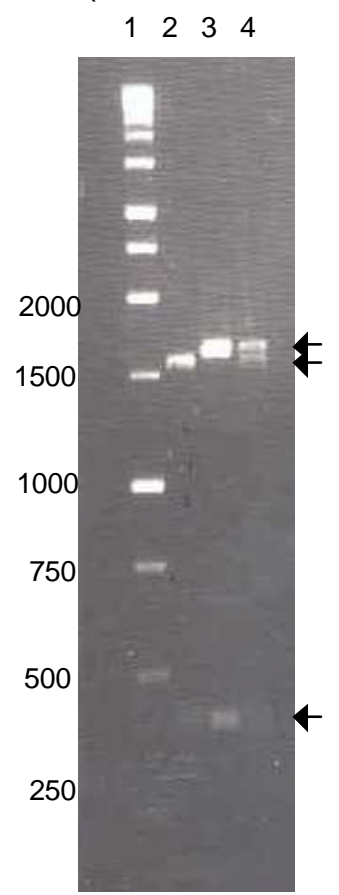

Figura 5 - Padrão de restrição obtido com digestão dos fragmentos Bl-16/RPS2, Lc201/RPS2 e do $F_{1} /$ RPS2, com enzima de restrição Xba I. (1) Padrão de peso molecular 1Kb Ladder (Promega); (2) Br16/RPS2; (3) Lc201/RPS2 (4) F $/$ RPS2. 


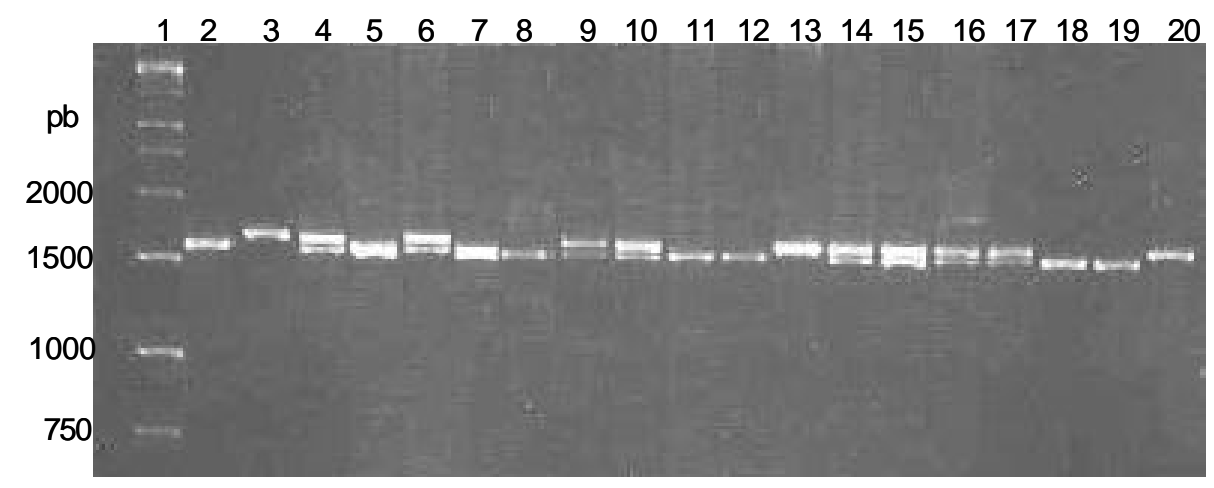

Figura 6 - Padrão de restrição obtido com digestão dos fragmentos Bl-16/RPS2, Lc201/RPS2 e fragmentos amplificados nos indivíduos $F_{1}$ e $F_{2}$ com enzima de restrição Xba I. (1) Padrão de peso molecular 1Kb Ladder (Promega); (2) Br16; (3) Lc201; (4) $\mathrm{F}_{1}$; (5 a 20) $\mathrm{F}_{2}$. 
Tabela 2. Área foliar lesionada (AFL) e genótipo obtido pela restrição com a enzima $X b a l$ na população $F_{2}$.

\begin{tabular}{|c|c|c|c|c|c|}
\hline Indivíduos & $\mathrm{AFL}\left(\mathrm{cm}^{2}\right)$ & Genótipo & Indivíduos & AFL $\left(\mathrm{cm}^{2}\right)$ & Genótipo \\
\hline 1 & 13,38 & A & 48 & 6,21 & $\mathrm{H}$ \\
\hline 2 & 16,91 & $\mathrm{H}$ & 49 & 6,07 & $\mathrm{H}$ \\
\hline 3 & 13,02 & A & 50 & 6,27 & $\mathrm{H}$ \\
\hline 4 & 16,85 & A & 51 & 8,32 & B \\
\hline 5 & 9,49 & $\mathrm{H}$ & 52 & 1,2 & $\mathrm{H}$ \\
\hline 6 & 6,89 & $\mathrm{H}$ & 53 & 1,44 & $\mathrm{H}$ \\
\hline 7 & 7,13 & A & 54 & 1,07 & $\mathrm{H}$ \\
\hline 8 & 6,19 & A & 55 & 2,1 & $\mathrm{H}$ \\
\hline 9 & 12,93 & B & 56 & 1,72 & $\mathrm{H}$ \\
\hline 10 & 8,53 & $\mathrm{H}$ & 57 & 1,58 & $\mathrm{H}$ \\
\hline 11 & 8,49 & $\mathrm{H}$ & 58 & 0,35 & $\mathrm{H}$ \\
\hline 12 & 9,96 & $\mathrm{H}$ & 59 & 0,35 & B \\
\hline 13 & 9,25 & $\mathrm{H}$ & 60 & 1,59 & B \\
\hline 14 & 13,05 & A & 61 & 1,46 & $\mathrm{H}$ \\
\hline 15 & 6,73 & A & 62 & 1,4 & A \\
\hline 16 & 6,35 & B & 63 & 0,98 & $\mathrm{H}$ \\
\hline 17 & 9,18 & $\mathrm{H}$ & 64 & 0,69 & B \\
\hline 18 & 10,16 & $\mathrm{H}$ & 65 & 0,32 & $\mathrm{H}$ \\
\hline 19 & 11,76 & B & 66 & 1,81 & $\mathrm{H}$ \\
\hline 20 & 8,59 & $\mathrm{H}$ & 67 & 0,69 & $\mathrm{H}$ \\
\hline 21 & 8,6 & $\mathrm{H}$ & 68 & 1,87 & $\mathrm{H}$ \\
\hline 22 & 14,84 & B & 69 & 1,6 & $\mathrm{H}$ \\
\hline 23 & 7,02 & B & 70 & 1,67 & $\mathrm{H}$ \\
\hline 24 & 7,09 & $\mathrm{H}$ & 71 & 1,59 & $\mathrm{H}$ \\
\hline 25 & 7,06 & B & 72 & 1,09 & $\mathrm{H}$ \\
\hline 26 & 7,22 & $\mathrm{H}$ & 73 & 0,92 & $\mathrm{H}$ \\
\hline 27 & 7,8 & $\mathrm{H}$ & 74 & 1,79 & $\mathrm{H}$ \\
\hline 28 & 7,52 & B & 75 & 0,67 & $\mathrm{H}$ \\
\hline 29 & 7,46 & B & 76 & 2,16 & $\mathrm{H}$ \\
\hline 30 & 6,35 & A & 77 & 2,06 & $\mathrm{H}$ \\
\hline 31 & 6,93 & B & 78 & 1,85 & $\mathrm{H}$ \\
\hline 32 & 6,03 & $\mathrm{H}$ & 79 & 1,64 & $\mathrm{H}$ \\
\hline 33 & 10,64 & B & 80 & 1,87 & A \\
\hline 34 & 8,5 & B & 81 & 1,7 & A \\
\hline 35 & 14,32 & $\mathrm{H}$ & 82 & 1,27 & $\mathrm{H}$ \\
\hline 36 & 7,01 & $\mathrm{H}$ & 79 & 1,06 & $\mathrm{H}$ \\
\hline 37 & 6,86 & $\mathrm{H}$ & 80 & 2,13 & A \\
\hline 38 & 6,87 & $\mathrm{H}$ & 81 & 2,12 & $\mathrm{H}$ \\
\hline 39 & 6,54 & B & 82 & 2,07 & $\mathrm{H}$ \\
\hline 40 & 16,55 & $\mathrm{H}$ & 83 & 0,14 & B \\
\hline 41 & 8,76 & B & 84 & 0,21 & $\mathrm{H}$ \\
\hline 42 & 13,8 & B & 85 & 1,73 & A \\
\hline 43 & 6,17 & B & 86 & 0,18 & $\mathrm{H}$ \\
\hline 44 & 6,18 & $\mathrm{H}$ & 87 & 0,22 & $\mathrm{H}$ \\
\hline 45 & 8,67 & $\mathrm{H}$ & 88 & 0,32 & B \\
\hline 46 & 10,62 & B & 89 & 2,06 & B \\
\hline 47 & 12,32 & B & 90 & 0,67 & B \\
\hline
\end{tabular}




\subsubsection{Expressão do homólogo BI-16/RPS2 em Brassica oleracea}

No experimento para verificar a patogenicidade do isolado os sintomas foram visualizados uma semana após a inoculação. No parental resistente, observou-se um pequeno halo amarelado em volta da área de inoculação, enquanto no parental suscetível a área sintomática foi maior (Figura 7). Para avaliar a expressão do homólogo Bl-16/RPS2 em resposta a inoculação, o RNA mensageiro extraído de folhas coletadas 24 horas após a inoculação foi transcrito e submetido à amplificação com os oligonucleotídeos específicos. Um fragmento de 453 pares de bases foi amplificado nos pais resistente e suscetível (Figura 8). No tratamento controle sem inoculação também houve a amplificação do referido fragmento. No controle negativo da reação de PCR usando apenas RNA mensageiro não houve amplificação, indicando não haver contaminação das amostras com DNA genômico. No controle positivo contendo DNA genômico, por sua vez, houve amplificação de uma banda de aproximadamente 500 pares de base, indicando a otimização da reação de PCR e a inexistência de introns dentro do fragmento seqüenciado, tal como inexiste no gene RPS2 de $A$. thaliana. Esse fragmento foi seqüenciado e revelou homologia com os mesmos genes de resistência descritos no item

4.1.1.2. No alinhamento entre as seqüências nucleotídicas de Bt16/RPS2 e a seqüência obtida a partir de DNA complementar, observou-se o alinhamento entre as bases 479 e 931 . Dentro desta região que apresentou 97\% de similaridade, foram observadas 14 substituições de bases (3\%) e duas inserções ou deleções (0,44\%). Em relação a Lc201, o fragmento de DNAc 
apresentou $93 \%$ de identidade e situou-se entre os nucleotídeos 482 e 937 da seqüência de Lc201/RPS2. Foram observadas 25 (5,5\%) substituições e 3 inserções ou deleções $(0,6 \%)$. $\mathrm{Na}$ análise de Northern blot, não foi possível detectar a presença de fragmentos que indicasse a expressão do gene B $\mathrm{B}$ 16/RPS2. Tal fato pode ser devido ao baixo nível de expressão do gene e a sensibilidade da análise uma vez que o controle positivo, utilizando como sonda o gene de $\beta$-actina de B. oleracea (AF044573), só foi possível detectar até 100 picogramas de DNA, indicando que expressões em concentrações menores não podem ser detectadas (Figura 9).

Os resultados do RT-PCR indicam que os genes B116/RPS2 e Lc201/RPS2 são expressos constitutivamente, em concordância com outros trabalhos de genes de resistência.
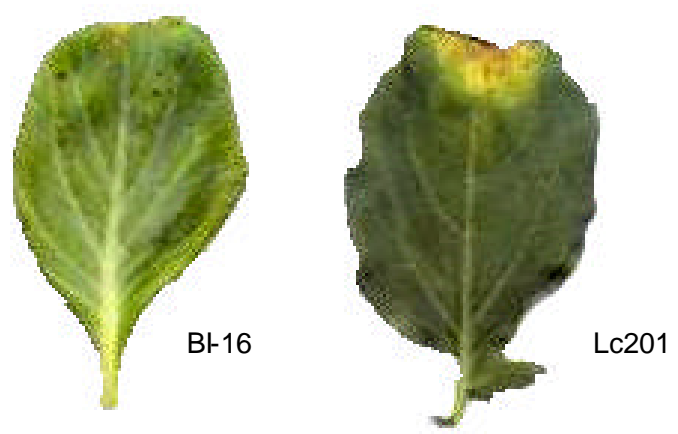

Figura 7 - Sintomas nas linhagens parentais BL16 e Lc201 uma semana após inoculação com isolado PHW 1205 de Xanthomonas campestris pv. campestris. 


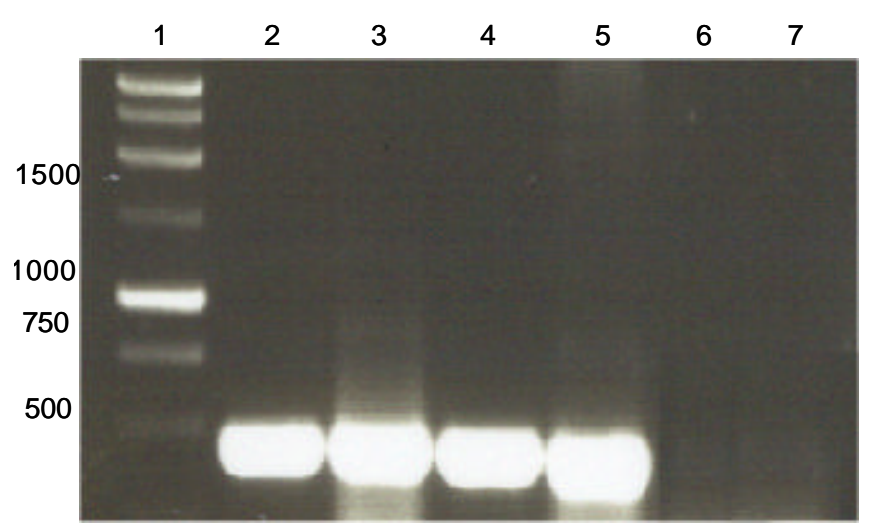

Figura 8 - PCR de DNAc obtido de folhas 24 horas após a inoculação com Xanthomonas campestris pv. campestris. (1) $1 \mathrm{~Kb}$ DNA ladder (Promega); (2 e 3) controle positivo com DNA genômico de Bł16 e Lc201, respectivamente; (4 e 5) PCR com DNAc de Bl-16 e Lc201, respectivamente; (6 e 7) controle negativo com RNA mensageiro.

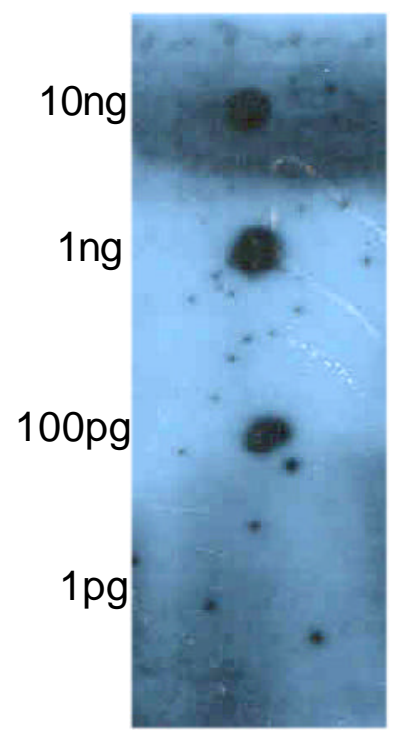

Figura 9 - Perfil de hibridização com sonda de $\beta$-actina. Diluições variaram de 10ng à1pg de DNA. Diluição a 1 pg não houve hibridização. 
4.2 Clonagem e caracterização genética de fragmentos homólogos a genes de resistência em Zea mays

\subsubsection{Clonagem de fragmentos em Zea mays}

\subsubsection{Amplificação de fragmentos com os oligonucleotídeos Pics}

O oligonucleotídeo Pic18 amplificou fragmentos que apresentaram polimorfismo de comprimento entre as linhagens parentais AG41 e AG45 e o híbrido AG41xAG45 (Figura 10). A linhagem AG41 apresentou um fragmento de aproximadamente 650 pares de bases, enquanto que a linhagem AG45 apresentou um fragmento de aproximadamente 490 pares de bases. Os dois fragmentos foram amplificados no híbrido. A reação foi repetida três vezes para certificar-se da presença do polimorfismo. Em todas as reações, o polimorfismo foi constante para as linhagens. 


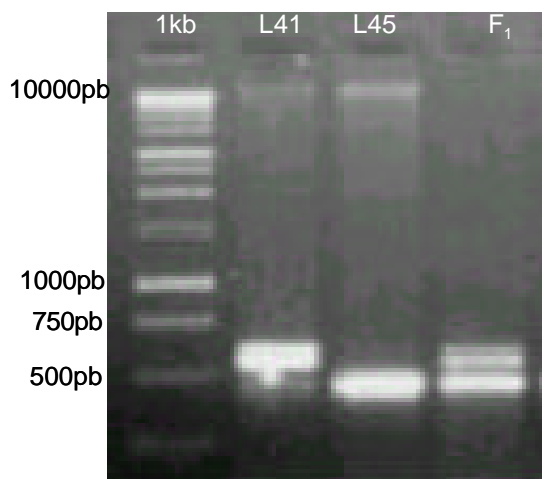

Figura 10 - Fragmentos das linhagens parentais AG41, AG45 e do híbrido AG41xAG45, amplificados com os oligonucleotídeos específicos Pic18. 1Kb Ladder é o marcador de peso molecular (Promega, Madison, WI).

Para o conjunto de oligonucleotídeos denominado Pic 17, apenas um fragmento de aproximadamente 300 pares de bases foi amplificado em todas as linhagens e nos híbridos (Figura 11). Não houve polimorfismo de comprimento entre nenhum material vegetal.

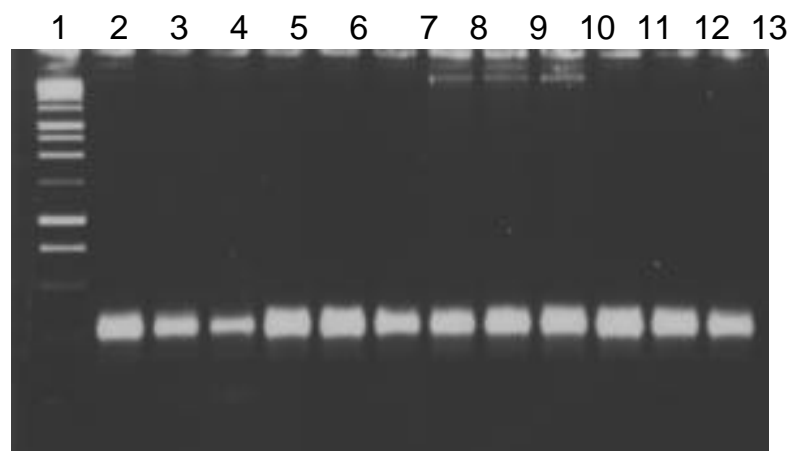

Figura 11 - Perfil de amplificação do oligonucleotídeo Pic 17. Amostra 1: marcador de peso molecular $1 \mathrm{~kb}$ ladder (Promega, Madison, WI); 2: DAS21; 3: DAS6; 4: híbrido DAS21x DAS6, 5: DAS4, 6: DAS6, 7. DAS4x DAS6; 8. DAS95; 9; DAS21; 10: DAS95xDAS21; 11: AG41; 12: AG45; 13:AG41xAG45. 


\subsubsection{Digestão dos produtos de PCR nas linhagens parentais}

Dentre as enzimas testadas para o oligonucleotídeo Pic17, nenhuma revelou sítio de restrição, apesar das enzimas selecionadas serem de corte freqüente.

\subsubsection{Seqüenciamento de fragmentos amplificados}

Os fragmentos amplificados com os oligonucleotídeos Pic18 foram extraídos de gel de agarose e seqüenciados. As seqüências foram editadas e a análise por meio de BLASTN revelou homologia com a seqüência Pic18 (AF056158) previamente descrita por Collins et al. (1998). A seqüência do fragmento da linhagem suscetível AG45 apresentou 97\% de homologia com a mesma seqüência.

Os fragmentos amplificados com oligonucleotídeo Pic17 foram seqüenciados utilizando-se os próprios oligonucleotídeos específicos Pic17 no sentido anverso e reverso. As seqüências dos fragmentos foram editadas e a análise por meio de BLAST revelou homologia com a seqüência Pic17 (AF056157) previamente descrita por Collins et al. (1998), conforme esperado. Nos dois casos foi obtido homologia com a seqüência de RNA mensageiro de milho denominada PCO145579 (AY106802.1). 


\subsubsection{Análise de cosegregação do fragmento Pic18}

Uma vez identificada a homologia dos fragmentos polimórficos com a seqüência do Pic18 disponível no banco de dados do NCBI, procedeu-se a amplificação de DNA de indivíduos obtidos do cruzamento entre a linhagem resistente a Exserohilum turcicum convertida e a linhagem suscetível. Nesta análise, foram incluídos indivíduos que apresentaram a nota S5, que indica alta suscetibilidade, segundo escala de notas descrita por Esteves (1989) na análise fenotípica da população segregante obtida por Ogliari (1999). Foram genotipados 30 indivíduos, previamente avaliados fenotipicamente. A estratégia utilizada foi aquela proposta por Zhang et al. (1994), onde apenas os indivíduos segregantes recessivos são genotipados, pois são homozigotos para alelos no loco Ht e contribuem significativamente para expressão do caráter em questão.

Através do teste de $X^{2}$, observou-se que a segregação do marcador Pic18 se adequou a proporção esperada de $1 \mathrm{Ht} \mathrm{M}_{1} \mathrm{M}_{1}: 1 \mathrm{HtM}_{1} \mathrm{M}_{2}$ no extremo de suscetibilidade no caso de segregação independente para o caso de um monogene em uma primeira geração de retrocruzamento. Assim, observou-se que não há ligação entre o marcador Pic18 e o gene $H t$. Dezenove indivíduos apresentaram genótipos idênticos ao do híbrido e 11 indivíduos tiveram genótipo idêntico ao parental suscetível.

Análise de ligação também foi feita pelo programa MAPMAKER versão 3.0 (Lander et al., 1987) com LOD score >2, através de genótipo no loco marcador Pic18 e locos microssatélites previamente localizados no cromossomo 2 (Ogliari, 1999). Nesta análise, também não foi observada ligação 
entre o loco amplificado por Pic18 e os locos microssatélites, confirmando que este marcador amplifica uma região distante dos locos previamente descritos como ligados ao gene $H t$ nesta população. Na figura 12 estão apresentados os perfis de bandeamento de parte dos indivíduos da população segregante. Os genótipos e fenótipos dos indivíduos encontram-se a seguir (Tabela 3).

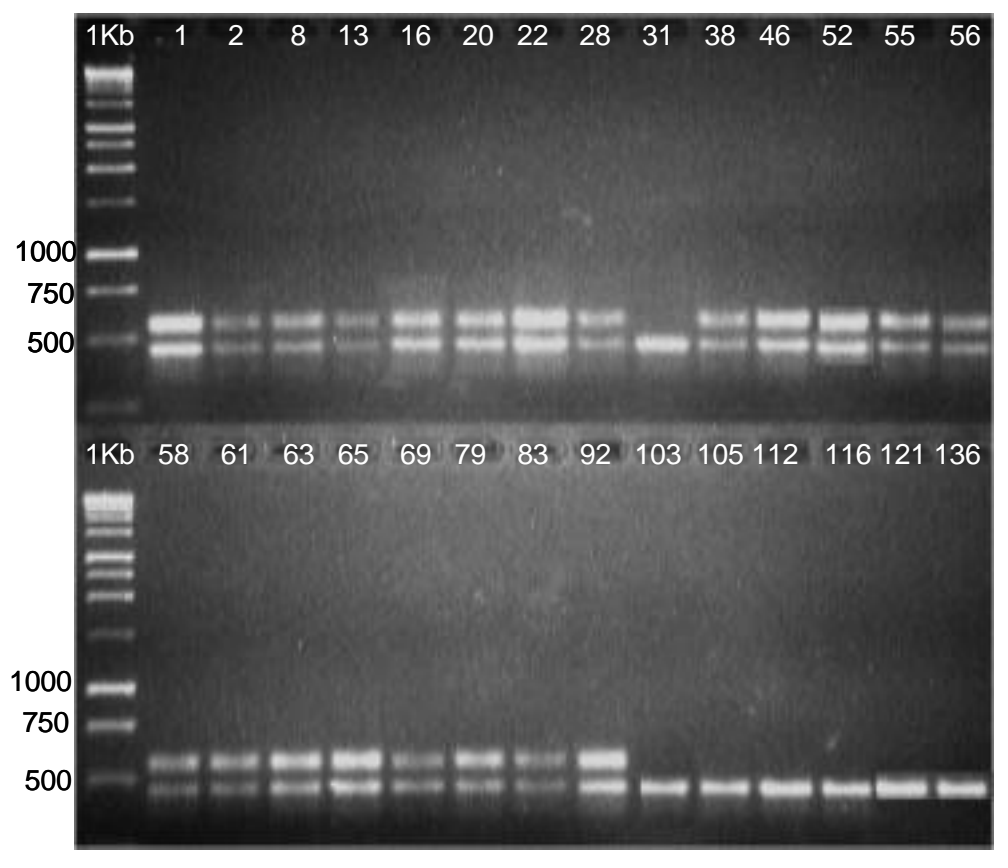

Figura 12 - Fragmentos amplificados com o oligonucleotídeo Pic18 em indivíduos da população segregante para resistência a Exserohilum turcicum. $1 \mathrm{~Kb}$ Ladder encontra-se na primeira linha de cada gel. Os demais são indivíduos da população segregante. 
Tabela 3. Fenótipos segundo a escala de notas descrita por Esteves (1989) e genótipos no loco Pic18 de indivíduos suscetíveis derivados de AG41 x AG45.

\begin{tabular}{ccc}
\hline Indivíduo & Fenótipo & Genótipo \\
\hline 1 & $\mathrm{~S} 5^{\mathrm{a}}$ & $\mathrm{H}$ \\
2 & $\mathrm{~S} 5$ & $\mathrm{H}$ \\
4 & $\mathrm{~S} 5$ & $\mathrm{H}$ \\
6 & $\mathrm{~S} 5$ & $\mathrm{H}$ \\
7 & $\mathrm{~S} 5$ & $\mathrm{H}$ \\
8 & $\mathrm{~S} 5$ & $\mathrm{H}$ \\
13 & $\mathrm{~S} 5$ & $\mathrm{H}$ \\
16 & $\mathrm{~S} 5$ & $\mathrm{H}$ \\
18 & $\mathrm{~S} 5$ & $\mathrm{H}$ \\
20 & $\mathrm{~S} 5$ & $\mathrm{H}$ \\
21 & $\mathrm{~S} 5$ & $\mathrm{H}$ \\
22 & $\mathrm{~S} 5$ & $\mathrm{H}$ \\
27 & $\mathrm{~S} 5$ & $\mathrm{H}$ \\
28 & $\mathrm{~S} 5$ & $\mathrm{H}$ \\
29 & $\mathrm{~S} 5$ & $\mathrm{H}$ \\
30 & $\mathrm{~S} 5$ & $\mathrm{H}$ \\
31 & $\mathrm{~S} 5$ & $\mathrm{~B}$ \\
32 & $\mathrm{~S} 5$ & $\mathrm{~B}$ \\
35 & $\mathrm{~S} 5$ & $\mathrm{~B}$ \\
37 & $\mathrm{~S} 5$ & $\mathrm{~B}$ \\
38 & $\mathrm{~S} 5$ & $\mathrm{H}$ \\
39 & $\mathrm{~S} 5$ & $\mathrm{~B}$ \\
40 & $\mathrm{~S} 5$ & $\mathrm{~B}$ \\
41 & $\mathrm{~S} 5$ & $\mathrm{~B}$ \\
45 & $\mathrm{~S} 5$ & $\mathrm{H}$ \\
46 & $\mathrm{~S} 5$ & $\mathrm{~B}$ \\
48 & $\mathrm{~S} 5$ & $\mathrm{~B}$ \\
50 & $\mathrm{~S} 5$ & $\mathrm{~B}$ \\
52 & $\mathrm{~S} 5$ & $\mathrm{H}$ \\
53 & $\mathrm{~S} 5$ & $\mathrm{~B}$ \\
\hline
\end{tabular}

${ }^{a}$ Indica que o indivíduo recebeu nota 5, com presença de lesões necróticas delimitadas, sem halo clorótico e com bordos mais escuros na periferia das lesões. $B=$ indivíduos com genótipo do parental L45/L45, H= Indivíduos com genótipo do híbrido AG41xAG45 


\subsubsection{Clonagem de fragmentos homólogos a ESTs de milho}

\subsubsection{Amplificação de fragmentos por meio de oligonucleotídeos baseados em ESTs de milho}

Foram sintetizados sete pares de oligonucleotídeos homólogos a ESTs envolvidos em resistência a patógenos (Tabela 4).

Tabela 4. Seqüências dos oligonucleotídeos sintetizados a partir de seqüências homólogas a ESTs de resistência em milho

\begin{tabular}{lll}
\hline EST & Direto $\left(5^{\prime}-3^{\prime}\right)$ & Reverso $\left(5^{\prime}-\right.$ 3') $^{\prime}$ \\
\hline PR41 & TGACAGTCGGCAATAATAAGCTG & CGTGTGGGATCACATCCATA \\
LRR & CATACAGCACGCCTACTCCA & CAGTACCACAGGGCGAACTA \\
ResFus & GTCCTCCTGCTGCTCCTG & CCTATTCCGATTTCCGATA \\
quitinase & GTGCCGGAGACCAACAAC & GCCCGTAGTTGAAGTTCCAG \\
Cf2/Cf5 & ACCAAGGGGCAACTGTA & CGGGGCTGTCAAATTGTTAT \\
PR1 & GTACCGGCCAAACAGCAG & GAGCTCCTGTCGGCTCAC \\
PDR & ACATCAGTCCGCTAGCCAGT & GCTGAAGAACCTCGACAAGA \\
\hline
\end{tabular}

Entre os sete pares de oligonucleotídeos testados, apenas os oligonucleotídeos LRR e PDR amplificaram fragmentos definidos nas linhagens e híbridos. Os oligonucleotídeos PR4, quitinase, ResFus, Cf2/Cf5 e PR1 não amplificaram fragmentos de DNA, apresentando sempre um rastro no gel de agarose. O iniciador LRR amplificou fragmentos de aproximadamente 500 pares de bases ao passo que o iniciador PDR amplificou fragmentos de aproximadamente 650 pares de bases (Figura 13). 


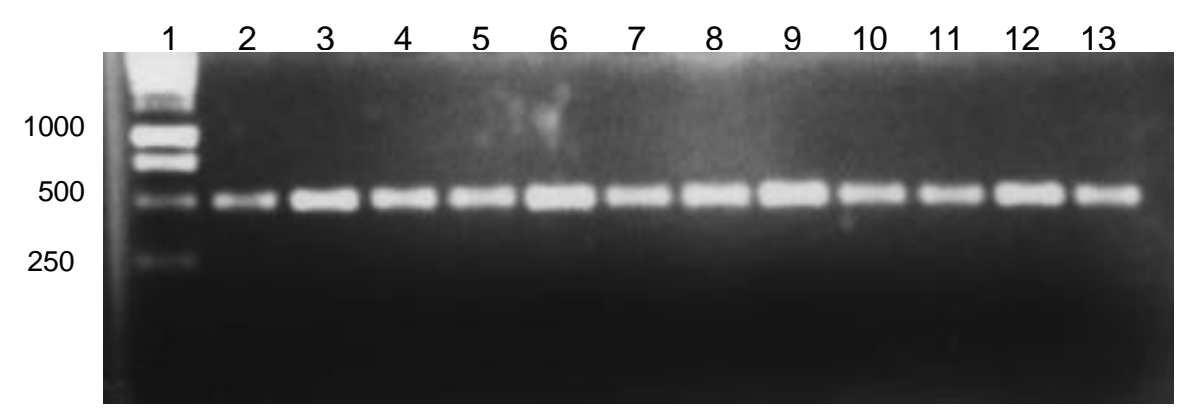

A

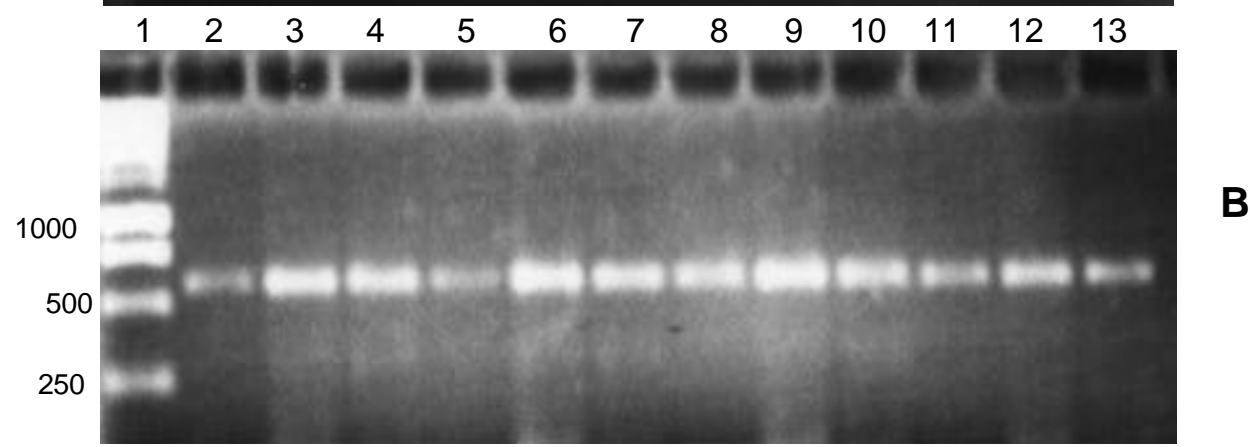

Figura 13 - Fragmentos obtidos com os oligonucleotídeos LRR (A) e PDR (B). 1: marcador de peso molecular $1 \mathrm{~Kb}$ Ladder (Promega, Madison, WI); 2: DAS21; 3: DAS6; 4: híbrido DAS21x DAS6, 5: DAS4, 6: DAS6, 7. DAS4x DAS6; 8. DAS95; 9; DAS21; 10: DAS95xDAS21; 11: AG41; 12: AG45; 13:AG41XAG45.

\subsubsection{Análise de polimorfismo de comprimento por meio de enzima de restrição}

Para análise de polimorfismo de comprimento entre os indivíduos parentais e os híbridos, os fragmentos produtos de PCR obtidos da amplificação foram digeridos com várias enzimas de restrição. Entre as enzimas testadas, apenas a enzima Alu I digeriu tanto os fragmentos amplificados pelo 
iniciador PDR como pelo iniciador LRR. Os fragmentos gerados pela enzima Alu I, menores de 250 pares de base, aparecem com pouca intensidade no gel de agarose 2\% (Figura 14 e 15). Um controle positivo para verificar a eficiência das enzimas foi feito por meio de digestão de $50 \mathrm{ng}$ de DNA do fago $\lambda$ com as enzimas usadas neste trabalho e todas as enzimas digeriram o DNA do fago $\lambda$. 


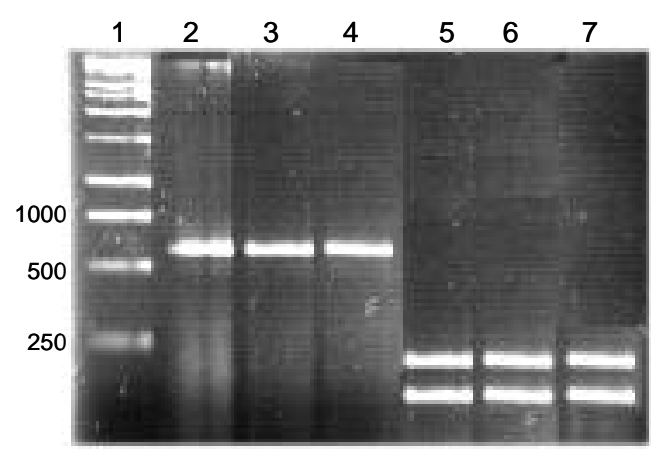

Figura 14 - Perfil de bandeamento obtido pela digestão dos fragmentos amplificados pelo iniciador PDR nos parentais AG41 e AG45 e no híbrido AG41xAG45 com Alu I. 1: 1 Kb DNA Ladder (Promega, Madison, WI) 2, 3 e 4 linhagem AG41, AG45 e híbrido AG41xAG45, sem digerir, repectivamente; 5, 6 e 7, AG41, AG45 e AG41xAG45 digeridos com Alu I, respectivamente.

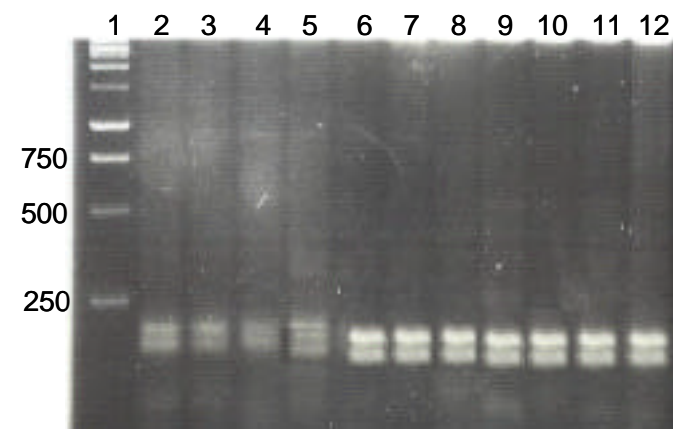

Figura 15 - Perfil de bandeamento obtido pela digestão dos fragmentos amplificados pelo iniciador LRR com a enzima Alu I nas linhagens parentais. 1Kb Ladder (Promega, Madison, WI); 2: linhagem DAS21; 3: linhagem DAS6; 4: híbrido DAS21x DAS6, 5: DAS4, 6: DAS6, 7. DAS4x DAS6; 8. DAS95; 9; DAS21; 10: DAS95xDAS21; 11: AG41; 12: AG45; 13:AG41xAG45. 


\section{DISCUSSÃO}

A alta homologia de seqüência dos fragmentos BL16/RPS2 e Lc201/RPS2 com genes de resistência que possuem motivos NBS e LRR e a similaridade com o gene RPS2 sugerem que estes façam parte de um loco envolvido na resistência a patógenos. A presença de domínios de associação à membrana, característica do gene RPS2, reforça tal sugestão.

A homologia de seqüências entre domínios conservados de diferentes genes de resistência não indica necessariamente que estes também sejam genes de resistência. Segundo Graham et al. (2000), estes motivos não são comuns apenas aos genes aqui estudados. Proteínas inibidoras de poligalacturonases e extensinas também contêm motivos LRRs. Embora estas proteínas estejam envolvidas no processo de interação entre o hospedeiro e patógeno, elas são consideradas proteínas de defesa e não de resistência (Jones, 2001). É possível ainda que estes genes não sejam funcionais. Genes não funcionais ocorrendo em cluster de genes homólogos a genes de resistência foram relatados em tomateiro e arroz (Ori et al., 1997; Song et al., 1997). A maior dificuldade até o momento, todavia, persiste na identificação desses genes funcionais. No caso do RPS2 por exemplo, os alelos que codificam para suscetibilidade apresentam pequenas variações em relação aos 
alelos de resistência (Caicedo et al., 1999). Aliado a este fator, outros genes foram identificados como atuando no processo de reconhecimento do gene avrRpt2 em Arabidopsis thaliana. Ao menos seis aminoácidos presentes na região LRR deste gene foram identificados como responsáveis pela reação de reconhecimento. Este fato indica a presença de outros alelos auxiliando no processo de resistência codificado pelo RPS2 (Banerjee et al., 2001). Assim, é possível que o homólogo descrito neste trabalho seja um alelo presente em um cluster de gene envolvido na resistência a Xanthomonas campestris pv. campestris (Camargo et al., 1995), muito embora os resultados de Southern blot indicaram a existência de apenas uma cópia do gene tanto em Arabidopsis (Mindrinos et al., 1994) quanto em diferentes espécies do gênero Brassica (Wroblewski et al., 2000).

O fato de o homólogo BL16/RPS2 não estar associado à resistência a xcc não é único. Também em $B$. oleracea, foi demonstrado que quatro locos homólogos a genes de resistência não foram associados a QTLs de resistência (Vicente \& King, 2001). Os autores atribuem este fato ao pequeno número de genes de resistência identificados nesta espécie em comparação a outras espécies mais estudadas. A ausência de ligação entre locos homólogos com genes de resistência pode ocorrer pelo fato destes genes não possuírem os motivos utilizados para construção dos oligonucleotídeos (Collins et al., 1998). Estes homólogos podem, entretanto, ser utilizados como marcadores moleculares em populações segregantes para genes de resistência a outros patógenos. De acordo com Melotto \& Kelly (2001), os genes homólogos podem 
não estar sempre associados com o fenótipo de resistência e podem estar ligados a genes de resistência mas a uma grande distância. Para comprovar a associação de um gene com a resistência a um determinado patógeno, plantas suscetíveis devem ser transformadas geneticamente e expressar o fenótipo de resistência quando inoculadas (Shen et al., 1998).

A amplificação do fragmento BH16/RPS2 a partir de DNA complementar (DNAc) demonstrou que este é parte de um gene expresso constitutivamente. A expressão constitutiva é a mais comum entre os genes de resistência, a exemplo do gene RPS2, que também é expresso em tecido não infectado (Mindrinos et al., 1994). O fragmento de 453 pares de bases obtido a partir de DNA complementar alinhou entre os nucleotídeos 473 e 953 da seqüência de DNA genômico de BH16/RPS2 e entre os nucleotídeos 475 e 958 da seqüência de Lc201/RPS2. Esta região se sobrepõe à região do fragmento Bl16/RPS2 que contém a alteração no quadro de leitura localizado no nucleotídeo 782 . Na seqüência de DNA complementar foram observadas 14 substituições de bases e duas inserções e ou deleções em relação à seqüência de Bl-16/RPS2. Com base nestas diferenças entre as seqüências, duas possibilidades podem ser consideradas: a primeira é que exista um erro na identificação da fase de leitura. Assim, após o seqüenciamento do gene inteiro, com identificação da seqüência promotora e códon de iniciação, é possível que ocorra alteração no quadro de leitura da seqüência e a fase correta seja identificada. Ocorrência de alteração no quadro de leitura e presença de códon de terminação em homólogos já foram descritas (Vicente \& King, 2001). A segunda possibilidade é 
que duas cópias diferentes deste gene estejam sendo identificadas. Deste modo, a cópia identificada a partir do RNA mensageiro transcrito e que estaria sendo expressa seria homóloga àquela identificada a partir do DNA genômico. Aliado a isto, clones de ESTs de $A$. thaliana com $80 \%$ de homologia com 0 DNAc parcial foi mapeado no cromossomo 4 desta espécie, junto ao gene RPS2. Em couve-flor, quatro conjuntos de oligonucleotídeos amplificaram fragmentos homólogos a genes de resistência a partir de DNA complementar e DNA genômico. Estes fragmentos foram digeridos com enzimas de restrição e o padrão de fragmentos analisados. Dois conjuntos de oligonucleotídeos apresentaram o mesmo número de fragmentos na digestão de produtos obtidos da amplificação de DNA genômico e DNA complementar. Os outros dois conjuntos apresentaram diferenças no padrão de digestão dos produtos de PCR, apresentando um número menor de fragmentos na digestão dos produtos amplificados com DNA complementar que na digestão daqueles amplificados com DNA genômico. Essa observação sugere que um determinado número de genes foi amplificado a partir de DNA genômico e apenas parte destes genes foram expressos em níveis detectáveis nos tecidos amostrados (Vicente \& King, 2001). Diferenças no número de cópias também foram relatadas para o gene RPP8 de Arabidopsis. O acesso Col-0 apresenta apenas uma cópia, ao passo que o acesso Ler apresenta cópias duplicadas (Dangl \& Jones, 2001).

Nas análises de identificação de fragmentos homólogos em milho, o oligonucleotídeo Pic18 amplificou fragmentos polimórficos entre as linhagens resistente e suscetível a E. turcicum gerando um marcador molecular. 
Entretanto, na análise da população segregante não foi detectada ligação entre tal marcador e o gene $\mathrm{Ht}$ previamente identificado no cromossomo 2 (Ogliari, 1999). É possível que uma outra cópia esteja sendo amplificada, uma vez que este oligonucleotídeo provavelmente amplifica uma região duplicada (Collins et al., 1998) sendo uma cópia localizada no cromossomo 2 e a outra no cromossomo 4. Neste caso, é interessante a utilização deste marcador em populações segregantes para resistência a ferrugens do milho, uma vez que a cópia do cromossomo 4 está ligada a genes de resistência a ferrugens. Ademais, recentemente outros genes de resistência a $E$. turcicum foram identificados na linhagem AG41, mas ainda não foram mapeados (Ogliari, comunicação pessoal). O marcador Pic18 pode estar também amplificando um destes outros genes. Collins et al. (1998) identificaram onze diferentes classes de genes homólogos e nenhuma delas mostrou-se ligada aos genes $h t 2, h t n 1$, hm2 e msv1.

Os demais fragmentos amplificados com os oligonucleotídeos Pic17, LRR e PDR não apresentaram polimorfismo entre as linhagens avaliadas. Segundo Bhattramakki et al. (2000), polimorfismos de seqüência única ocorrem no genoma de milho em média a cada 70 bases. Entretanto, em fragmentos de aproximadamente 300 pares de bases foi observada uma menor ocorrência desse tipo de polimorfismo. Ocorrência muito provável em virtude da domesticação dessa espécie. Neste trabalho, foram amplificados fragmentos de 500 a 600 pares de bases, tamanho ainda relativamente pequeno para ocorrência de polimorfismos. As enzimas utilizadas neste trabalho são enzimas 
de corte freqüente mas, mesmo assim, não detectaram nenhum polimorfismo. Parece comum que o polimorfismo ocorra mais em introns que em exons (Caicedo et al., 1999; Iwata et al., 2001). Assim, considerando que estas seqüências homólogas façam parte de um loco envolvido na resistência e portanto sejam expressas, a quantidade de polimorfismo deveria ser menor, como observado. Ausência de polimorfismo também pode estar relacionada à similaridade genética entre as linhagens analisadas, uma vez que estas são todas oriundas da mesma população sintética (Morello, 2000).

Em feijoeiro, apenas um grupo de fragmentos homólogos ao gene Pto foi polimórfico, enquanto outros quatro foram monomórficos mesmo entre genótipos de diferentes centros de origem (Vallad et al., 2001). Independente da espécie, a quantidade de polimorfismo observada tem sido baixa. Aproximadamente $40 \%$ dos fragmentos homólogos em linhagens de girassol segregantes para resistência a míldio (Plasmopara halstedii) não foram polimórficos. Em pimentão, 39\% tiveram o mesmo comportamento (Gedil et al., 2001; Pflieger et al., 2001). Em soja, por sua vez, um marcador ligado ao gene de resistência ao vírus do mosaico da soja (Soybean mosaic vírus) apresentou duas substituições de bases e um sítio de inserção/deleção de quatro bases entre as linhagens resistente e suscetível em um fragmento de 1349 pares de base (Jeong et al., 2002).

Marcadores obtidos por meio de polimorfismo de fragmentos amplificados são mais vantajosos em relação a outros tipos de marcadores pois baseiam-se na amplificação de DNA e digestão dos fragmentos amplificados e 
são herdados de maneira codominate e são quase sempre baseados em amplificação de DNA complementar ou ESTs. Desta forma, estes representam genes funcionais, uma vantagem em relação àqueles baseados em seqüências não funcionais.

A estratégia de utilização de fragmentos homólogos a genes de resistência deve ser considerada como uma ferramenta em potencial para trabalhos de mapeamento de genes, visto que o número de polimorfismo parece ser função do tamanho dos fragmentos amplificados, das enzimas de restrição utilizadas e da distância genética entre as populações. Assim, a utilização de populações obtidas de cruzamentos entre materiais geneticamente distantes pode gerar maior polimorfismo. 


\section{CONCLUSÕES}

Com base nos resultados pode-se concluir:

1 A utilização de seqüências conservadas entre genes de resistência para desenvolvimento de oligonulceotídeos é eficiente para amplificação de fragmentos homólogos a estes genes.

2 O fragmento homólogo ao gene RPS2 de Arabidopsis thaliana não está ligado a gene de resistência a Xanthomonas campestris pv. campestris na linhagem Bt16 de Brassica oleracea.

3 O fragmento homólogo ao gene RPS2 é expresso constitutivamente em B. oleracea.

4 Não há ligação entre o marcador Pic18 e o gene $H t$. Este marcador ainda pode estar no cromossomo 2, mas a uma distância maior que $50 \mathrm{cM}$ do gene $H t$.

5 Não há polimorfismo entre os fragmentos homólogos a ESTs de milho devido a similaridade genética entre as linhagens estudadas. 


\section{REFERÊNCIAS BIBLIOGRÁFICAS}

AARTS, M.G.M.; HEKKERT, B.L.; HOLUB, E.B.; BEYNON, J.L.; STIEKEMA, W.J.; PEREIRA, A. Identification of R-gene homologous DNA fragments genetically linked to disease resistance loci in Arabidopsis thaliana. Molecular Plant Microbe Interactions, v.11, n.4, p.251-258, 1998.

ALTSCHUL, S.F.; MADDEN, T.L.; SCHAFFER, A.A.; ZHANG, Z.; MILLER, W.; LIPMAN, D.J. "Gapped BLAST and PSHBLAST: a new generation of protein database search programs". Nucleics Acids Research, v.25, p.3389-3402, 1997.

ANDERSON, P.A.; LAWRENCE, G.J.; MORRISH, B.C.; AYLIFFE, M.A.; FINNEGAN, E.J.; ELLIS, J.G. Inactivation of the flax rust resistance gene $M$ associated with loss of a repeated unit within the leucine-rich repeat coding region. The Plant Cell, v.9, p.641-651, 1997.

AXTELL, M.J.; McNELLIS, T. W.; MUDGETT, M.B.; HSU, C. S.; STASKAWICZ, B. Mutational analysis of the Arabidopsis RPS2 disease resistance gene and corresponding Pseudomonas syringae avrRpt2 avirulence gene. Molecular Plant Microbe Interactions, v.14, n.2, p.181-188, 2001. 
BANERJEE, D.; ZHANG, X.; BENT, A.F. The leucine-rich repeat domain can determine effective interaction between RPS2 and other host factors in Arabidopsis RPS2-mediated disease resistance. Genetics, v.158, p.439450, 2001.

BENT, A.F. Plant disease resistance genes: function meets structure. The Plant Cell, v.8, p.1757-1771, 1996.

BENT, A.F.; KUNKEL, B.N.; DAHLBECK, D.; BROWN, K.L.; SCHMIDT, R.; GIRAIDAT, J.; LEUNG, J.; STASKAWICZ, B.J. RPS2 of Arabidopsis thaliana: a leucine-rich repeat class of plant disease resistance genes. Science, v.265, p.1856-1860, 1994.

BERGELSON, J.; KREITMAN, M.; STAHL, E.A.; TIAN, D. Evolutionary dynamics of plant R-genes. Science, v.292, p.2281-2285, 2001.

BHATTRAMAKKI, D.; CHING, A.; MORGANTE, M.; DOLAV, M.; REGISTER, J.; SMITH, H.; TINGEY, S.; RAFALSKI, J.A. Conserved single nucleotide polymorphism (SNP) haplotypes in maize. Http://www.intlpag.org/8/abstracts/pag8420.html. (26 Nov. 2002).

BOTELLA, M.A.; COLEMAN, M.J.; HUGHES, D.E.; NISHIMURA, M.T.; JONES, J.D.G.; SOMERVILLE, S. C. Map positions of 47 Arabidopsis sequences with sequence similarity to disease resistance genes. The Plant Journal, v.12, p.1197-1211, 1997.

CAICEDO, A.L.; SCHAAL, B.A.; KUNKEL, B.N. Diversity and molecular evolution of the RPS2 resistance gene in Arabidopsis thaliana. Proceedings of the National Academy of Sciences of the United States of America, v.96, p.302-306, 1999. 
CAMARGO, L.E.A.; WILLIAMS, P.H.; OSBORN, T.C. Mapping of quantitative trait loci controlling resistance of Brassica oleracea to Xanthomonas campestris pv. campestris in the field and greenhouse. Phytopathology, v.85, n.10, p.1296-1300, 1995.

CHEN, X.M.; LINE, R.F.; LEUNG, H. Genome scanning for resistance-gene analogs in rice, barley, and wheat by high-resolution electrophoresis. Theoretical Applied Genetics, v.97, p.345-355, 1998.

CHIN, E.C.L.; SENIOR, M.L.; SHU, H.; SMITH, J.S.C. Maize simple repetitive DNA sequences: abundance and allele variation. Genome, v.39, p.866873, 1996.

COLLINS, N.; PARK, R.; SPIELMEYER, W.; ELLIS, J.; PRYOR, A.J. Resistance gene analogs in barley and their relationship to rust resistance genes. Genome, v.44, p.375-381, 2001.

COLLINS, N.; WEBB, C.A.; SEAH, S.; ELLIS, J.G.; HULBERT, S.H.; PRYOR, A. The isolation and mapping of disease resistance gene analogs in maize. Molecular Plant-Microbe Interactions, v.11, n.10, p.968-978, 1998.

DANGL, J.L.; JONES, J.D.G. Plant pathogens and integrated defense responses to infection. Nature, v.411, n.14, p.826-833, 2001.

DIXON, M.S.; JONES, D.A.; KEDDIE, J.S.; THOMAS, C.M.; HARRISON, K.; JONES, JDG. The tomato Cf-2 disease resistance locus comprises two functional genes encoding leucine-rich repeat proteins. Cell, v.84, p.451459, 1996. 
ESTEVES, M.C.F. Reações a Exserohilum turcicum (Pass.) Leonard \& Suggs em milho (Zea mays L.) e variabilidade do patógeno. Piracicaba, 1989. 55p. Dissertação (Mestrado) - Escola Superior de Agricultura "Luiz de Queiróz", Universidade de São Paulo.

FEUILLET, C.; SCHACHERMAYR, G.; KELLER, B. Molecular cloning of a new receptor-like kinase gene encoded at the Lr10 disease resistance locus of wheat. The Plant Journal, v.11, n.1, p.45-52, 1997.

FLOR, H.H. Current status of the gene-for-gene concept. Annual Review of Phytopathology, v.9, p.275-296, 1971.

GEDIL, M.A.; SLABAUGH, M.B.; BERRY, S.; JOHNSON, R.; MICHELMORE, R.; MILLER, J.; GUYLA, T.; KNAPP, S.J. Candidate disease resistance genes in sunflower cloned using conserved nucleotide-binding site motifs: Genetics mapping and linkage to the downy mildew resistance gene Pl1. Genome, v.44, p.205-212, 2001.

GRAHAM, M.A.; MAREK, L.F.; LOHNES, D.; CREGAN, P. SHOEMAKER, R.C. Expression and genome organization of resistance gene analogs in soybean. Genome, v.43, p.86-93, 2000.

GRANT, M.R.; GODIARD, L.; STRAUBE, E.; ASHFIELD, T.; LEWALD, J.; SATTLER, A.; INNES, R.W.; DNGL, J.L. Structure of the Arabidopsis RPM1 gene enabling dual specificity disease resistance. Science, v.269, p.843846, 1995.

GRANT, M.R.; McDOWELL, J.M.; SHARPE, A.G.; ZABALA, M.T.; LYDIATES, D.J.; DANGL, J.L. Independent deletions of pathogen-resistance gene in 
Brassica e Arabidopsis. Proceedings of the National Academy of Sciences of the United States of America, v.95, p.15843-15848, 1998.

GREEN, P. Against a whole-genome shotgun. Genome Research, v.7, n.5, p.410-417, 1997.

HAMMOND-KOSACK, K.E.; JONES, J.D.G. Plant disease resistance genes. Annual Review Plant Physiology and Plant Molecular Biology, v.48, p.575-607, 1997.

HANAHAN, D. Studies on transformation of Escherichia coli with plasmids. Journal of Molecular Biology, v.166, n.4, p. 557-580, 1983.

HOFMANN, K.; BUCHER, P.; FALQUET, L.; BAIROCH, A. The PROSITE database, its status in 1999. Nucleic Acids Research, v.27, p.215-219, 1999.

HOISINGTON, D.; KAIRHALLAH, M.; GONZALEZ-DE LEON, D. Laboratory protocols: CIMMYT applied Molecular Genetics Laboratory. 2. ed. México: D. F. CIMMYT, 1994. 51p.

HULBERT, S.H.; WEBB, C.A.; SMITH, S.M.; SUN, Q. Resistance gene complexes: evolution and utilization. Annual Review of Phytopathology, v.39, p.285-312, 2001. 
HUTCHESON, S.W. Current concepts of active defense in plants. Annual Review of Phytopathology, v.36, p.59-90, 1998.

IWATA, H.; UJINO-IHARA, T.; YOSHIMURA, K.; NAGASAKA, K.; MUKAI, Y.; TSUMURA, Y. Cleaved amplified polymorpic sequence markers in sugi, Cryptomeria japonica D. Don, and their locations on a linkage map. Theoretical Applied Genetics, v.103, p.881-895, 2001.

JEONG, S.C.; KRISTIPATI, S.; HAYES, A.J.; MAUGHAN, P.J.; NOFFSINGER, S.L.; GUNDUZ, I.; BUSS, G.R.; SAGHAI MAROOF, M.A. Genetic and sequence analysis of markers tightly linked to the Soybean mosaic virus resistance gene, Rsv3. Crop Science, v.42, p.265-270, 2002.

JONES, D.A.; THOMAS, C.M.; HAMMOND-KOSACK, K.E.; BALINT-KURTI, P.J.; JONES, J.D.G. Isolation of the tomato $C f-9$ genes for resistance to Cladosporium fulvum by transposon tagging. Science, v.266, p.789-793, 1994.

JONES, J.D.G. Putting knowledge of plant disease resistance genes to work. Current Opinion in Plant Biology, v.4, p.281-287, 2001.

KANAZIN, V.; MAREK, L.F.; SCHOEMAKER, R.C. Resistance gene analogs are conserved and clustered in soybean. Proceedings of the National Academy of Sciences of the United States of America, v.93, p.1174611750, 1996.

LANDER, E.S.; GREEN, P.; ABRAHAMSON, J.; BARLOW, A.; DALY, M.J.; LINCOLN, S.E.; NEWBURG, L. MAPMAKER: an interactive computer package for constructing primary genetic linkage maps of experimental and natural populations. Genomics, v.1, p.174-181, 1987. 
LAWRENCE, G.J.; FINNEGAN, E.J.; AYLIFFE, M.A.; ELLIS, J.G. The L6 gene for flax rust resistance is related to the Arabidopsis bacterial resistance gene RPS2 and the tobacco viral resistance gene N. The Plant Cell, v.7, p.11951206, 1995.

LEE, J.M.; GRANT, D.; VALLEJOS, C.E.; SHOEMAKER, R.C. Genome organization in dicots. II. Arabidopsis is a "bridging species" to resolve genome evolution events among legumes. Theoretical Applied Genetics, v.103, p. 765-773, 2001.

LEISTER, D.; BALLVORA, A.; SALAMINI, F.; GEBHARDT, C. A PCR-based approach for isolating pathogen resistance genes from potato with potencial for wide application in plants. Nature Genetics, v.14, p.421-429, 1996.

LEISTER, D.; KURTH, J.; LAURIE, D.A.; YANO, M.; SASAKI, K.; GRANER, A.; SCHULZE-LEFERT, P. RFLP and physical mapping of resistance gene homologues in rice (O. sativa) and barley (H. vulgare). Theoretical Applied Genetics, v.98, p.509-520, 1999.

LEISTER, D.; KURTH, J.; YANO, M.; SASAKI, T.; DEVOS, K.; GRANER, A.; SCHULZE-LEFERT, P. Rapid reorganization of resistance gene homologues is cereal genomes. Proceedings of the National Academy of Sciences of the United States of America, v.95, p. 370-375, 1998.

LEWIN, B. Genes VII. Oxford: University Press, 2000. 990p. 
LURDERER, R.; RIVAS, S.; NÜRNBERGER, T.; MATTEI, B.; VAN der HOOVEN, H.W.; VAN der HOORN, R. A.L.; ROMEIS, T.; WEHRFRITZ, J.; BLUME, B.; NENNSTIEL, D.; ZUIDEMA, D.; VERVOORT, J.; DE LORENZO, G.; JONES, J.D.G.; DE WI T.G.M.; JOOSTEN, M.H.A.J. No evidence for binding between resistance gene product $C f-9$ of tomato and avirulence gene product AVR9 of Cladosporium fulvum. Molecular Plant Microbe Interactions, v.14, n.7, p.867-876, 2001.

MAGO, R.; NAIR, S.; MOHAN, M. Resistance gene analogues from rice: cloning, sequencing and mapping. Theoretical Applied Genetics, v.99, p.50-57, 1999.

MALVAS, C.C., COELHO, R.M.S.; CAMARGO, L.E.A. Identificação de genes de resistência a podridão negra em Brassica oleracea por meio da genotipagem seletiva. Fitopatologia Brasileira, v.24, n.2, p.143-148, 1999.

MARCZEWSKI, W.; FLIS, B.; SYLLER, J.; SCHÄFER-PREGL, R.; GEBHARDT, C. A major quantitative trait locus for resistance to potato lefroll virus is located in a resistance hotspot on tomato chromosome XI and is tightly linked to $\mathrm{N}$-gene-like markers. Molecular Plant Microbe Interactions, v.14, n.12, p.1420-1425, 2001.

MARTIN, G.B.; BROMMONSCHENKEL, S.H.; CHUNWONGSE, J.; FRARY, A.; GANAL, M.W.; SPIVEY, R.; WU, T.; EARLE, E.D.; TANKSLEY, S.D. Mapbased cloning of a protein kinase gene conferring disease resistance in tomato. Science, v.262, p.1432-1436, 1993. 
MELOTTO, M.; KELLY, J.D. Fine maping of the Co-4 locus of common bean reveals a resistance gene candidate, COK-4, that encodes for a protein kinase. Theoretical Applied Genetics, v.103, p.508-517, 2001.

MINDRINOS, M.; KATAGIRI, F.; YU, G-L.; AUSUBEL, F.M. The A. thaliana disease resistance gene RPS2 encodes a protein containing a nucleotidebinding site and leucine-rich repeats. Cell, v.78, p.1089-1099, 1994.

MORELLO, R.M.S.C. Pesistência em milho (Zea mays L.) a Colletotrichum graminicola (Ces.) Wils. Piracicaba, 2000. 94p. Tese (Doutorado) - Escola Superior de Agricultura "Luiz de Queiróz", Universidade de São Paulo.

OGLIARI, J. B. Identificação e localização de um gene de resistência de milho a Exserohilum turcicum (Pass.) Leonard \& Suggs. através do uso de marcadores mirossatélites. Piracicaba, 1999. 115p. Tese (Doutorado) Escola Superior de Agricultura "Luiz de Queiroz", Universidade de São Paulo.

OHMORI, T.; MURATA, M.; MOTOYOSHI, F. Characterization of disease resistance gene-like sequences in near-isogenic lines of tomato. Theoretical Applied Genetics, v.96, p.331-338, 1998.

ORI, N.; ESHED, Y.; PARAN, I.; PRESTING, G.; AVIV, D.; TANKSLEY, S.; ZAMIR, D.; FLUHR, R. The I2C family from the wilt disease resistance locus 12 belongs to the nucleotide binding, leucine-rich repeat supefamily of plant resistance genes. The Plant Cell, v.9, p.521-532, 1997. 
PARKER, J.E.; COLEMAN, M.J.; SZABÓ, V.; FROST, L.N.; SCHMIDT, R.; van der BIEZEN, E.; MOORES, T.; DEAN, C.; DANIELS, M.J.; JONES, J.D.G. The Arabidopsis downy mildew resistance gene RPP5 shares similarity to the Toll and interleukin-1 receptors with $N$ and L6. The Plant Cell, v.9, p.879-894, 1997.

PARNISKE, M.; WULFF, B.B.H.; BONNEMA, G.; THOMAS, C.M.; JONES, D.A.; JONES, J.D.G. Homologues of the Cf-9 disease resistance gene (Hcr9s) are present at multiple loci on the short arm of tomato chromossome 1. Molecular Plant Microbe Interactions, v.12, n.2, p.93-102, 1999.

PFliEgER, S.; PALLOIX, A.; CARANTA, C.; BLATTES, A. Defense response genes co-localize with quantitative disease resistance loci in pepper. Theoretical Applied Genetics, v.103, p.920-929, 2001.

SAMBROOK, J., FRITSCH, E.F; MANIATIS, T. Molecular Cloning: A laboratory manual. 2.ed. New York: Cold Spring Harbor Laboratory Press, 1989. 3v.

SCHAAL, B.A.; OLSEN, K.M. Gene genealogies and population variation in plants. Proceedings of the National Academy of Sciences of the United States of America, v.97, n.13, p.7024-7029, 2000.

SEAH, S.; SIVASITHAMPARAM, K.; KARAKOUSIS, A.; LAGUDAH, E.S. Cloning and characterization of a family of disease resistance gene analogs from wheat and barley. Theoretical Applied Genetics, v.97, p.937-945, 1998. 
SHEN, K.A.; MEYERS, B.C.; ISLAM-FARIDI, M.N.; CHIN, D.B.; STELLY, D.M.; MICHELMORE, R.W. Resistance gene candidates identified by PCR with degenerate oligonucleotide primers map to clusters of resistance genes in lettuce. Molecular Plant Microbe Interactions, v.11, n.8, p.815-823, 1998.

SHEN, K.A.; CHIN, D.B.; ARROYO-GERCIA, R.; OCHOA, O.E.; LAVELLE, D.O.; WROBLEWSKI, T.; MEYERS, B.C.; MICHELMORE, R.W. Dm3 is one member of large constitutively expressed family of nucleotide binding site-Leucine-rich repeat encoding genes. Molecular Plant Microbe Interactions, v.15, n.3, p. 251-261, 2002.

SONG, F.; GOODMAN, R.M. Molecular biology of disease resistance in rice. Physiological and Molecular Plant Pathology, v.59, p.1-11, 2001.

SONG, W-Y.; PI, L-Y.; WANG, G.L.; GARDNER, J.; HOLSTEN, T.; RONALD, P.C. Evolution of the rice Xa21 disease resistance gene family. The Plant Cell, v.9, p.1279-1287, 1997.

SONG, W-Y.; WANG, G-L.; CHEN, L-L.; KIM, H-S.; PI, L-Y.; HOLSTEN, T.; GARDNER, J.; WANG, B.; ZHAI, W-X.; ZHU, L-H.; FAUQUET, C.; RONALD, P. A receptor kinase-like protein encoded by the rice disease resistance gene, Xa21. Science, v.270, p.1804-1806, 1995.

VALLAD, G.; RIVKIN, M.; VALLEJOS, C.; McCLEAN, P. Cloning and homology modelling of a Pto-like protein kinase family of common bean (Phaseolus vulgaris L.). Theoretical Applied Genetics, v.103, p.1046-1058, 2001.

VICENTE, J.G.; KING, G.J. Characterisation of disease resistance gene-like sequences in Brassica oleracea L. Theoretical Applied Genetics, v.102, p.555-563, 2001. 
VINATZER, B.A.; PATOCCHI, A.; GIANFRANCESCHI, L.; TARTARINI, S.; ZHANG, HB.; GESSLER, C.; SANSAVINI, S. Apple contains receptor-like gene homologous to the Cladosporium fulvum resistance gene family of tomato with a cluster of genes cosegegating with $V f$ apple scab resistance. Molecular Plant Microbe Interactions, v.14, n.4, p.508-515, 2001.

WANG, G.L.; SONG, W.Y.; RUAN, D.L.; SIDERIS, S.; RONALD, P.C. The cloned gene, Xa-21, confers resistance to multiple Xanthomonas oryzae pv. oryzae isolates in transgenic plants. Molecular Plant Microbe Interactions, v.9, n.9, p.850-855, 1996.

WHITHAN, S.; DINESH-KUMAR, S.P.; CHOI, D.; HEHL, R.; CORR, C.; BAKER, B. The product of the tobacco mosaic virus resistance gene $N$ : similarity to toll and the interleukin-1 receptor. The Cell, v.78, p.1101-1115, 1994.

WIAME, I.; SWENNEN, R.; SÁGI, L. PCR-based cloning of candidate disease resistance genes from banana (Musa acuminata). Acta Horticultura, v.521, p.51-57, 2000.

WROBLEWSKI, T.; COULIBALY, S.; SADOWSKI, J.; QUIROS, C.F. Variation and phylogenetic utility of the Arabidopsis thaliana RPS2 homolog in various species of the tribe brassiceae. Molecular Phylogenetic Evolution, v.16, n.3, p. $440-448,2000$.

YOSHIMURA, S.; YAMANOUCHI, U.; KATAYOSE, Y.; TOKI, S.; WANG, Z.; KONO, I.; KURATA, N.; YANO, M.; IWATA, N.; SASAKI, T. Expression of Xa1, a bacterial blight-resistance gene in rice, is induced by bacterial inoculation. Proceedings of the National Academy of Sciences of the United States of America, v.95, p.1663-1668, 1998. 
YU, Y.G.; BUSS, G.R.; SAGHAHMAROOF, M.A. Isolation of a superfamily of candidate disease-resistance genes in soybean based on a conserved nucleotide-binding site. Proceedings of the National Academy of Sciences of the United States of America, v.93, p.11751-11756, 1996.

ZHANG, Q.; SHEN, B.Z.; DAI, X.K.; MEI, M.H.; SAGHAHMAROOF, M.A.; LI, Z.B. Using bulked extremes and recessive class to map genes for photoperiod-sensitive genic male sterility in rice. Proceedings of the National Academy of Sciences of the United States of America, v.91, p.8675-8679, 1994.

ZHU, H. CANNON, S.B.; YOUNG, N.D.; COOK, D.R. Phylogeny and genomic organization of the TIR and Non-TIR NBS-LRR resistance gene family in Medicago truncatula. Molecular Plant Microbe Interactions, v.15, n.6, p.529-539, 2002. 